\title{
REVISTA THESIS JURIS
}

Thesis Juris

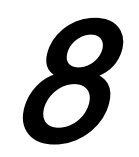

\section{A CRISE DO PODER JUDICIÁRIO COMO FATOR DETERMINANTE PARA A OCORRÊNCIA DA RELATIVIZAÇÃO DA COISA JULGADA}

The crises of the Judiciary as a factor for determining the occurrence of relativization of res judicata

\section{Rennan Faria Krüger Thamay}

Advogado, consultor jurídico, avaliador de revistas jurídicas e parecerista. Doutorando em Direito pela UNLP e pela PUC/RS. Professor de cursos preparatórios para concursos públicos, do IMED/CETRA/RS, do CIUSP, da FESDEP, do IDC, da Casa do Concurseiro, da LEX Magister, do Estratégia Concursos, da Escola Superior de Direito SP, da Grendal University - UniGrendal e da Olford Walters University - UniOlwa

\section{RESUMO}

Crise do Poder Judiciário é uma ocorrência muito relevante e hodierna que afeta a todos e merece ser combatida visando a solvência das problemáticas que ela causa. Para solver algumas das conseqüências prejudiciais nasceu a noção de relativização da coisa julgada que poderia tornar a decisão "mutável", tendo papel relevante e pontuado na 
discussão, visto que com esse instituto flexibilizador muitas injustiças que possam ter sido praticas podem ser superadas e inclusive alteradas. Solucionar a celeuma da crise do Judiciário não é algo fácil, mas também não resta impossível. Algumas das possíveis soluções seria uma aplicação mais efetiva da fundamentação das decisões judiciais, um aumento de responsabilidades para os magistrados frente às suas decisões e, por fim, propiciar a aplicação da celeridade, não fugindo da idéia da duração razoável do processo que deve ser observado com toda a cautela, adequando-se essas à adimplência do contraditório e da ampla defesa.

PALAVRAS-CHAVE: Crise do Poder Judiciário. Relativização da coisa julgada. Ocorrência da relativização da coisa julgada decorrente da crise do Judiciário.

\section{ABSTRACT}

Crisis of the judiciary is a very important and today's occurrence that affects everyone and needs to be tackled in order to solvency problems it causes. To solve some of the harmful consequences of relativity was born the notion of res judicata which could make the decision "changeable", have an important role in the discussion and punctuated, whereas with this institute flexible many injustices that may have been practices can be overcome and even changed. Solving the crisis stir the judiciary is not easy, but there remains impossible. Some of the possible solutions would be a more effective application of the reasoning of judicial decisions, increased responsibilities for judges facing their decisions and ultimately support the implementation of speed, not running away from the idea of reasonable duration of the process that must be observed with all caution, adapting these to the payments of the contradictory and full defense.

Keywords: Crisis of the Judiciary. Relativization of res judicata. The occurrence of relativization of res judicata arising from the crisis in the judiciary. 


\section{SUMÁRIO}

Introdução. 1. A crise do Poder Judiciário. 2. A relativização da coisa julgada. 3. A relativização da coisa julgada como decorrência da crise do Poder Judiciário. Considerações finais. Referências bibliográficas.

\section{INTRODUÇÃO}

Nossa sociedade imediatista caminha a passos largos para um futuro do qual não sabemos o possível resultado, principalmente pela história que nosso país vivenciou, um país muito "jovem" e que, diferentemente dos países europeus, desenvolveu-se até o presente momento de forma precoce, passando por diversas fases de forma acelerada e chegando à pósmodernidade em muito menos tempo que outros países.

Todo esse crescimento é interessante, principalmente por trazer novas perspectivas para as pessoas que vivem o presente, rememorando o passado de lutas e de vitórias que propiciarão um futuro belo, prometendo muitas conquistas e vitórias ${ }^{1}$. Para tudo isso, passaremos pela análise da existência da crise do Poder Judiciário que foi capaz de, buscando amenizar os seus efeitos danosos, instalar a relativização da coisa julgada, que se serve a flexibilizar aquelas decisões que são inadequadas e que se tornaram dessa maneiras em decorrência da crise que vivencia o Judiciário.

Passando pela análise da existência da crise do Judiciário, que será amplamente demonstrada através da percepção dos pontos em que essa crise se instalou, sendo muito influente em diversas situações.

\footnotetext{
${ }^{1}$ Essa análise a partir de um passado iluminado é relevante para que o futuro seja influenciado por um passado vitorioso e belo, isso é relevante para que a nossa sociedade não ande em um futuro nebuloso, fazendo vívidas as palavras do douto jurista Frances Tocqueville - que foi magistrado em 1827 -, que o passado, quando não mais ilumina o futuro, deixa o espírito andando nas trevas. In: TOCQUEVILLE, Alexis de. La démocratie em Amérique, Paris: Garnier: Flammarion, 1951, t. II, cap. VIII, p. 336.
} 
Dentro dessa perspectiva será transcorrida a análise da relativização da coisa julgada que, nesses casos, se dão em decorrência da crise do Judiciário que acaba por prejudicar a todos, influindo em direitos e deveres de forma gravosa.

Dentro de toda essa problemática será perceptível a importância que deve ser dada a essas averiguações, que poderão nos levar a novos caminhos que façam com que todos tenham seus direitos levados a sério, como já afirmava Ronald Dworkin.

Portanto, o grande objetivo dessa análise é poder conceber, a partir da observação de variadas correntes, uma forma coesa de tentar solucionar, quando menos ajudar, as problemáticas que foram posta em decorrência da crise, que fez com que os magistrados, em variados casos, decidissem de forma acelerada sem o cuidado com a feitura da justiça, que fundamenta a relativização da res iudicata, que poderá amenizar o sofrimento de muitos cidadãos que ficariam sem os seus direitos.

\section{A CRISE DO PODER JUDICIÁRIO}

Nossa sociedade vivencia hoje muitas ocorrências, relações aceleradas, contratações adesivas e uma constante busca desmedida de satisfação das demandas, conseqüência natural de uma sociedade que vive o imediatismo e não mais a celeridade ${ }^{2}$.

Nossa sociedade é apressada e muito afoita em vários aspectos, digamos que um exemplo seja a realidade que o país passa hoje, por viver não mais na modernidade, mas, sim, na pós-modernidade ${ }^{3}$.

\footnotetext{
${ }^{2}$ Deve-se tomar o devido cuidado para que as coisas não se acelerem por demais, visto que o direito deve seguir o seu tempo normal, sem uma aceleração exacerbada e desmotivada que prejudicaria e muito a natural preservação de um direito em sua essência máxima. (OST, François. O tempo do direito. Lisboa: Instituto Piaget, 1999, p. 39.)

${ }^{3}$ Nesse sentido ver os seguintes autores: JAYME, Erik. Cours général de droit intenacional prive, In recueil des cours, Académie de droit intenacional, t, 251, 1997, p. 36-37; MARQUES, Claudia Lima. Contratos no código de defesa do consumidor: o novo regime das relações contratuais, 4. ed. rev., atual. e ampli., incluindo mais de 1.000 decisões jurisprudenciais. São Paulo, RT, 2002, p.155-175. LYOTARD, Jean-François. O pós-moderno, Rio de Janeiro: Olympio Editora, 1986. KUMAR, Krishan. Da sociedade pós-industrial à pós-moderna, Rio de Janiro: Jorge Zahar Editor, 1997. HARVEY, David. Condição pós-moderna, São Palo: Edições Loyola, 1992. DELACAMPAGNE, C. História da Filosofia no Século XX, Rio de Janeiro: Jorge Zahar Editor, 1995. VATTIMO, Gianni. O Fim da Modernidade: niilismo e hermenêutica na cultura pós-moderna, Lisboa: Editorial
} 
Tudo isso veio de uma evolução muito forte que a sociedade de nosso país vivenciou, um crescimento que supera a velocidade de países europeus ou até de outros países que tenham também muito mais tempo de existência do que o Brasil.

A busca por celeridade ${ }^{4}$ não é, em sua origem, ruim, mas se observada de forma incorreta pode acarretar muitos problemas e, por vezes, até macular direitos que deveriam ser observados com o devido passar do tempo e transcurso de uma demanda.

Frente a todo esse frenesi o que começa a acontecer é a crise ${ }^{5}$, estendendo-se tanto para institutos não jurídicos como para os jurídicos, passando tanto pelo direito material ${ }^{6}$ como processual $^{7}$, para quem tem essa concepção dualista e não monista.

Neste ponto encontramos a crise de institutos jurígenos, como havíamos referido anteriormente, como também a crise frente a instituições e poderes, como é o caso do Judiciário ${ }^{8}$.

O Poder Judiciário ${ }^{9}$, que sempre foi bem visto por sua diligência e cuidado para com os direitos dos cidadãos, passa hoje, de forma muito severa, por uma crise ${ }^{10}$ real e muito

Presença, 1987. FEATHERSTONE. Cultura de consumo e Pós-modernismo, São Paulo: Studio Nobel, SESC, 1995. GIDDENS. "A vida em uma sociedade pós-tradicional", In: BECK, GIDDENS \& LASH, 1997. CAMPBELL, C. The Romantic Ethic and the Spirit of Modern Consumerism, Oxford: Blackwell,1987. SANTOS, Boaventura de Souza. Pela Mão de Alice: O social e o político na pós-modernidade, São Paulo: Cortez, 1997. BAUMAN, Zygmunt. Modernidade e Ambivalência, Rio de Janiro: Jorge Zahar Editor, 1999. ROUANET, S. P. As razões do iluminismo, São Paulo: Companhia das Letras, 1987.

${ }^{4}$ Deve-se guardar a Idéia de processo célere, para que possa dentro de um prazo razoável atingir os fins para os quais a ação foi proposta. Rememore-se que segundo o jurista Rui Portanova o princípio da celeridade derivado do da economia processual. In: PORTANOVA, Rui. Princípios do processo civil, $6^{\circ}$ ed., Porto Alegre: Livraria do Advogado, 2005, p. 171 e ss.

${ }^{5}$ A noção de crise que se apregoa aqui, antes de chegar à crise do Judiciário, é a crise do direito, que foi bem abordada por Shelma Kato in: KATO, Shelma Lombardi de. A crise do direito e o compromisso da libertação in Direito e justiça: A função social do Judiciário - org. José Eduardo Faria, $3^{\circ}$ ed., São Paulo: Ática, 1997, p. 167 e ss.

${ }^{6}$ Para aclarar sobre do direito material, se for o caso, observar a obra de BEDAUQE, José Roberto dos Santos. Direito e processo: influência do direito material sobre o processo, $4^{\circ}$ ed., rev. e ampli., São Paulo: Malheiros, 2006 , p. 54 e ss.

${ }^{7}$ Sobre a noção de direito processual civil recomenda-se SANTOS, Moacir Amaral. Primeiras linhas de direito processual civil, $7^{\circ}$ ed., São Paulo: Saraiva, 1980, p. 13 e ss.

${ }^{8} \mathrm{O}$ jurista Miguel Reale sabiamente se posiciona mostrando a existência da crise di Judiciário, argüindo que “ são deveras alarmantes os dados sobre o aumento progressivo das causas julgadas e em curso perante a Suprema Corte, desde a promulgação da Constituição de 1988, elevando-se de 6.637 em 1989 para 40.823 em 1997!"” sendo esse um dos fundamentos para o jurista. Ele ainda elenca mais um fundamento dizendo que " (...) as pretensões legítimas manifestadas por cidadãos de boa-fé que se vêem constrangidos, em face desse inaceitável comportamento governamental, a ingressar em juízo, gerando, desse modo, uma desnecessária multiplicação de demandas contra o Poder Público". In: REALE, Miguel. Crise do capitalismo e crise do Estado, São Paulo: Editora SENAC, 2000, p. 107-108. 
perigosa, que já trouxe problemas, e que sabidamente poderá trazer muito mais, o que poderá causar ainda mais prejuízos a toda a comunidade que depende das decisões dos magistrados para conseguir a efetividade de seus direitos e a solvência dos conflitos.

É no meio de toda essa problemática que as coisas se dão, uma crise que afeta toda a organização do Judiciário nacional, crise ocorrente como consequiência de toda uma história, não sendo fonte de algo recente, mas, sim, de varias ocorrências que se passam ao longo do tempo.

A crise não é única e exclusivamente do Poder Judiciário, por lógico, mas, sim, de grande parte dos institutos - a exemplo da coisa julgada ${ }^{11}$ que será debatida - e de outras instituições como as universidades ${ }^{12}$ que possuem o curso de direito.

O lastro da crise é forte e pode afetar muito aos direitos que os cidadãos possuem e que se verão, por tudo isso, prejudicados com essa concepção moderna que o Judiciário tem, decorrendo da nova visão que se tem do direito material e do processo $^{13}$, visão que busca, hoje, antes de tudo, a celeridade deixando, por vezes, o direito mal protegido em decorrência da vontade insana de velocidade para términos das demandas que crescem a cada dia ${ }^{14}$.

Muito se afirma, hodiernamente, da crise do Judiciário, de que esse poder não funcione bem e de que por essa ausência de bom funcionamento muitos prejuízos são

\footnotetext{
${ }^{9}$ Para compreender mais sobre o Judiciário pode ser observado LABOULAYE, Edouard René Lefebvre de. Do Poder Judiciário in: O poder judiciário e a Constituição, Porto Alegre: coleção AJURIS 4, 1977, p. 11 ss.

${ }^{10}$ Para complementar a busca da melhor compreensão sobre a crise existente averiguar SILVA, Ovídio A. Baptista da. In: Participação e processo, coord., Ada Pellegrini Grinover, São Paulo: RT, 1988, p. 98.

${ }^{11}$ Esse instituto, que será tratado com maior vagar em seguida, tem sido considerado relativizáevel, mutável, não sendo mais absoluto, em tese, como antes, passando-se a uma idéia de que as relações que foram constituídas e decididas judicialmente de forma incorreta deveriam ser modificadas, isso se dá tanto no processo objetivo como subjetivo. Neste sentido ver NERY JÚNIOR, Nelson [et. all.]. Código de processo civil comentado e legislação extravagante, $10^{\circ}$ ed. rev., ampli. e atual., São Paulo: RT, 2007, pp. 684-685.

12 Para essas peculiaridades das universidades que ofertam o curso de direito resta a crítica em decorrência na não aplicação de forma adequada da modalidade correta de ensino, passando ao acadêmico aquele ensino meramente formal, mas um formalismo que se torna desnecessário. Resta a critica, além desse ponto, da quantidade de faculdades de direito em nosso país, o que beira o absurdo. (SANTOS, Boaventura de Souza. Para uma revolução democrática da justiça, $2^{\circ}$ ed., São Paulo: Cortez, 2008, pp. 71-72).

${ }^{13}$ Sobre o direito processual civil, que para alguns não é considerado ciência, é considerado ciência pelo douto jurista Ovídio A. Baptista da Silva, verbis: O que há de surpreendente neste modo de compreender o direito é que apenas processo assumiu, para a doutrina, o caráter de ciência. $\mathrm{O}$ direito material conservou-se, para o pensamento moderno, um produto cultural e, como tal, sujeito às vicissitudes históricas e sociais. (SILVA, Ovídio A. Baptista da. Jurisdição, direito material e processo, Rio de Janeiro: Forense, 2008, p. 138.)

${ }^{14}$ Deve-se tomar o devido cuidado para que as coisas não se acelerem por demais, visto que o direito deve seguir o seu tempo normal, sem uma aceleração exacerbada e desmotivada que prejudicaria e muito a natural preservação de um direito em sua essência máxima. (OST, François. O tempo do direito. Lisboa: Instituto Piaget, 1999, p. 39.)
} 
causados. Tudo isso deve ser bem analisado, pois o Poder judiciário não funciona perfeitamente bem, assim como os demais, mas, também, não funciona mal.

\section{Pensando como o saudoso jurista Ovídio A. Baptista da Silva ${ }^{15}$, o Poder Judiciário,} não funciona mal, funciona bem levando em conta as limitações que foram impostas, por natural, em sua criação, algo que é muito natural. Esse poder foi criado para a solvência de $\operatorname{conflitos}^{16}$, gerando a conseqüente paz social ${ }^{17}$.

As críticas que são apontadas ao Judiciário devem ser, antes de tudo, analisadas para que delas se possa tirar aquilo que sirva, visando o melhoramento da condição de prestação da tutela jurisdicional por parte do Poder Judiciário ${ }^{18}$.

\footnotetext{
${ }^{15}$ O jurista Ovídio A. Baptista da Silva quando fala do Poder Judiciário aduz que "Ele funciona segundo os princípios e pressupostos imaginados por aqueles que o conceberam. Um ponto que não preocupa aqueles que se angustiam com os atuais problemas da administração da justiça é saber se a celeridade processual fora, realmente, concebida como um objetivo desejado pelo sistema. Ou seja, ainda não se demonstrou que nosso sistema processual fora programado para andar rápido. Ao contrário, ao priorizar o valor segurança, inspirada em juízos de certeza, como uma imposição das filosofias liberais do Iluminismo, o sistema renunciou à busca de efetividade - que nossas circunstâncias identificam com celeridade -, capaz de atender à solicitação de nossa apressada civilização pós-moderna. O Poder Judiciário funciona satisfatoriamente bem, em nosso país. Os problemas da Justiça são estruturais. Não funcionais. Ele atende rigorosamente bem ao modelo que o concebeu. Nossa percepção, no entanto, não alcança os problemas estruturais que condicionam a atual situação vivida pelo Poder Judiciário - seja porque eles se tornaram, para nossa compreensão, "naturais", como o dia e a noite e o movimento dos astros -, seja por parecerem-nos, de qualquer modo, como inalteráveis - a verdade é que a estrutura do sistema não é questionada, nem problematizada pelos que sofrem os danos de uma justiça que perdeu, até mesmo, a desejada funcionalidade. Pelo menos, os processualistas, que mais diretamente são atingidos por esse estado de coisas, não a questionam. Limitam-se a melhorar o seu funcionamento, como se o problema residisse em algum defeito funcional.

E ainda complementa: O problema, sem dúvida, não é funcional. Dentre outros muitos fatores desta ordem, ocorre-me o primeiro deles no próprio conceito e limites da jurisdição que praticamos como herança da Revolução Européia, desde suas origens medievais. O primeiro fator estrutural está na inabalável premissa redutora do conceito de jurisdição como simples declaração dos direitos, que é, por sua vez, o alicerce do procedimento ordinário e da interminável cadeia recursal. (SILVA, Ovídio A. Baptista da. Da função à estrutura - www.Baptistadasilva.com.br/artigos)

${ }^{16}$ Essa seria uma das formas de cumprir a função social do Poder Judiciário, neste sentido vejamos LOPES, José Reinaldo de Lima, in: FARIA, José Eduardo(coord.) [et. all]. Direito e justiça: A função social do judiciário, São Paulo: Ática, 1989, p. 123 e ss; Deve-se observar ainda as linhas traçadas por ROCCO, antigo professor da Universidade de Napoli, ao tratar da função jurisdicional in ROCCO, Ugo. Trattato di diritto processuale civile V. I, $2^{\circ}$ ed., Torino: Topografia Sociale Torinese, 1966, pp.46-48.

${ }^{17}$ (...) o que há de mais moderno já é alguma tendência a estabelecer um binômio de objetivos distribuídos entre o campo jurídico e social... ... entre outras tendências, preponderou a de que o escopo do processo reside na realização dos direitos subjetivos e (ou) confirmação da ordem jurídica, o objetivo cuja tarefa importante é a da manutenção da paz social da garantia da segurança jurídica. (DINAMARCO, Cândido Rangel. A Instrumentalidade do Processo, $9^{\circ}$ ed., São Paulo: Malheiros, 2001, p. 154).

${ }^{18}$ Ainda sobre a idéia de função social do Poder Judiciário vejamos as palavras do jurista Álvaro Felipe Oxley da Rocha in ROCHA, Álvaro Felipe Oxley da. Sociologia do direito: A magistratura no espelho, São Leopoldo: Editora UNISINOS, 2002, p. 27. "O Judiciário tem ocupado freqüentemente espaços nos cenários políticos nacional e internacional em razão de sua atuação nos mais diversos setores, seja agindo como agente mantenedor da origem vigente, seja como transformador dessa mesma ordem, à medida que cresce a sua atuação
} 
Claro que a crise, que se desenvolveu com o passar do tempo, veio causando enormes prejuízos, isso não se discute, mas se discute o motivo da existência da crise. Não de haver questionamento da existência ou não da crise, pois ela existe, mas devemos pensar o motivo de sua existência e de sua persistente confirmação.

Essas questões nos levaram a outro universo de discussão, onde veremos um Poder Judiciário abalroado de trabalho, acumulando a cada dia mais processos em seus respectivos cartórios, afetando-se cada vez mais a condição de pensar do magistrado.

Sabe-se que a quantidade de processos que existem hoje tornam a jurisdição ${ }^{19}$ cada vez mais complexa e difícil, pois a quantidade de ações que existem forçam o Judiciário a de forma rápida ${ }^{20}$ solucionar o litígio, por mais que de forma insatisfatória.

Essa é uma das mais fortes problemáticas que pode ser superada, mas que não será fácil de ser vencida, ainda mais pela atual condição do Poder Judiciário que conta com um quadro diminuto e insuficiente de servidores para dar conta de toda demanda que bate às portas do Judiciário. Isso pode e deve ser alterado, mas na atual situação econômica de nosso país creio ser algo complexo e muito difícil de ser realizar.

Além desta problemática gravosa outra de grande magnitude se impõe, qual seja a da ausência de manifestação do Poder Legislativo, que deveria elaborar leis ${ }^{21}$ que regulassem a vida em sociedade, por ser essa a função social deste Poder, mas que não é cumprida ${ }^{22}$. Esse não cumprimento gera uma serie de questões problemáticas das quais precisamos analisar e tomar a devida ciência, para buscar a solução.

modificadora das políticas de governo, impedindo ou dando nova direção às questões submetidas a seus agentes".

${ }^{19}$ Sobre o que seja jurisdição importante é observar MARINONI, Luiz Guilherme [et. all.]. Código de direito processual civil comentado, São Paulo: RT, 2008, p. 95 e ss.

${ }^{20}$ A celeridade deve ser empregada com moderação, visando não prejudicar o direito efetivamente constituído e pelo qual se instala o litígio judicial, pois nem sempre a decisão rápida terá o condão de ser adequada ou ainda correta. Assim, a celeridade, por mais importante que seja, tem limites que devem ser observados. In: SANTOS, Boaventura de Souza. Para uma revolução democrática da justiça, $2^{\circ}$ ed., São Paulo: Cortez, 2008, p. 27.

${ }^{21}$ Kelsen, quando em sua obra Teoria pura do direito constrói a idéia de que lei é direito e que por essa razão deveríamos estar submissos a lei, vide: KELSEN, Hans. Teoria pura do direito, $4^{\circ}$ Ed., São Paulo: Martins Fontes, 1994, p. 33 e ss.

${ }^{22}$ Idem., p. 21. Com a efetiva omissão do Poder Legislativo em relação a varias questões o Poder Judiciário toma a frente na solução dos conflitos que se formam a partir da ausência de manifestação do Legislativo, fazendo com que o Judiciário passe a solver as dúvidas existentes e que foram deixadas por aquele poder. Diga-se ainda que essa manifestação do Judiciário tem sido latente tanto em questões do Legislativo com também do Executivo. 
Os cidadãos que não tem as suas situações solucionadas pelo Poder Legislativo, que deveria legislar sobre uma determinada matéria, vão buscar socorro aos seus anseios junto ao Poder Judiciário, o que por mais uma vez faz com que o dito Poder precise gastar seu tempo para solver essas ocorrências perniciosas em decorrência da omissão do Legislativo, inflando ainda mais a estrutura do Poder Judiciário.

Isso não deveria ocorrer, o Legislativo deveria cumprir o seu papel de legislar e regulamentar o comportamento da sociedade de uma forma geral, o que por si só, além de cumprir a função social deste Poder, ajudaria o Judiciário a não ficar cada Vez mais sobrecarregado. Mas isso não ocorre, pois a omissão do Legislativo persiste e coloca, mais uma vez, o Judiciário em situação desprestigiada ${ }^{23}$ junto à sociedade, que acredita que o problema é deste poder quando em verdade essa demanda, geradora de morosidade ${ }^{24}$, é decorrência da inação do nosso Congresso Nacional.

Vemos uma grande problemática com tudo isso, pois o Judiciário acaba por fazer função que não seja a sua, qual seja a de legislar de forma indireta, fazendo nascer a figura do ativismo judicial $^{25}$, ou ainda da judicialização da política. O Judiciário passa a fazer às vezes de "legislador" quando sabe ser efetivamente, por delegação constitucional, julgador. Aqui surge um problema, pois se esse Poder foi concebido para julgar não deveria legislar, quer por não ter, em tese, condição e preparação para tanto, quer ainda por haver uma separação dos poderes $^{26}$, que limita a ação de cada um dos Poderes, visando a harmonia deste Poderes para

\footnotetext{
${ }^{23}$ O Poder Judiciário passa a ser mais desvalorizado pela sociedade a cada dia, seja por ser, para muitos, como a mera boca da lei, como também por ser um Poder moroso. Essa morosidade que advém da má prática do Poder Legislativo deve ser cessada para que o Judiciário possa novamente ganhar força e voltar a ser o Poder respeitado que sempre foi. Idem., p. 11.

${ }^{24}$ Sobre o tema da morosidade do Judiciário, caso seja necessário o esclarecimento , vide: ROCHA, Álvaro Felipe Oxley da. Sociologia do direito: A magistratura no espelho, São Leopoldo: Editora UNISINOS, 2002, p. 119 e ss.,

${ }^{25}$ Idem., p. 23.

${ }^{26}$ MONTESQUIEU, Charles de Secondat, Baron de. Do Espírito das Leis. São Paulo: Saraiva, 2000, p. 167-168. Também devemos observar Duverger, Maurice. Constitutions et documents politiques, Paris: PUF, 1974, p. 10. “Toute société dans laquelle la garantie dês droits n'est pás assurée, ni la séparation des pouvoirs déterminée, n’a point Constitution". Por tudo isso a separação dos poderes é relevantíssima, pois é a base inicial para um Estado forte. Ademais, conforme acentua o jurista português NUNO PIÇARRA, esta doutrina da separação de poderes remonta à Grécia e Roma antiga. ( PIÇARRA, Nuno. A Separação dos Poderes como doutrina e Princípio Constitucional - Um contributo para o estudo das suas origens e evolução. Coimbra : Coimbra Editora, 1989, p. 31.)

O autor lusitano identifica as origens da idéia da separação dos poderes no conceito de constituição mista de ARISTÓTELES em sua obra Política, segundo o qual: “(...) constituição mista, para Aristóteles, será aquela em que os vários grupos ou classes sociais participam do exercício do poder político, ou aquela em que o exercício da soberania ou o governo, em vez de estar nas mãos de uma única parte constitutiva da sociedade, é comum a
} 
que a sociedade ganhe maior efetividade com as atribuições partilhadas. Ressalte-se a exceção da teoria dos freios e contrapesos, onde cada um dos Poderes exerce um pouco das funções dos demais Poderes, mas de forma moderada e pontuada.

Ainda deve-se agregar a essas problemáticas, ressaltadas anteriormente, o costume litigante dos brasileiros que se acentua mais a cada dia. Nossa sociedade se mostra mais demandante e questionadora a cada dia e isso é bom até certo ponto, especificamente até onde se possa garantir a proteção de direitos e exigir o cumprimento de contratos, por exemplo, mas quando isso descamba para a idéia da simples e desmotivada demanda a problemática surge. $\mathrm{O}$ que se tem visto, com muita freqüência, é o crescente costume de demandar por qualquer coisa, fazendo o uso do meio processual e da maquina do Judiciário para discutir o óbvio, que poderia ser solucionado, por muitas vezes, pela simples composição tendo como exemplo a justiça restaurativa ${ }^{27}$.

Esse acontecimento também tem sido um forte fator de acumulo de processos junto ao Judiciário, o que faz com que a situação fique cada vez mais complexa, dotando de maior morosidade ${ }^{28}$ as demanda judiciais, prejudicando a obtenção dos direitos que são, por muitas das vezes, intrínsecos e subjetivos, que seriam de fácil e rápida proteção caso o volume de processos fosse menor, mas que se torna uma discussão longa em decorrência de toda essa exacerbação do direito de petição.

Varias conseqüências muito perniciosas surgem dessa crise que vivencia o Poder Judiciário $^{29}$, uma delas é bem esposada pelo jurista gaúcho Ovídio A. Baptista da Silva, quando fala da "justiça pasteurizada" ${ }^{30}$, que seria nada mais do que uma prestação da tutela

todas. Contrapõem-se-lhe, portanto, as constituições puras em que apenas um grupo ou classe social detém o poder político."'( Idem., p. 33.)

${ }^{27}$ A justiça restaurativa, que hodiernamente é estudada, é interessante pois parte da idéia de composição da lide, de solução da lide sem o transcurso natural da lide, que é, por sinal, muito delongado. Sobre justiça restaurativa deve ser miradas as lições que o eminente jurista SANTOS, Boaventura de Souza. Para uma revolução democrática da justiça, $2^{\circ}$ ed., São Paulo: Cortez, 2008, p. 58.

${ }^{28}$ A necessidade de pensar algo que possa agir contra a morosidade ou lentidão dos processos, algo que está sendo perceptível, sobre a busca de soluções veja OST, François. O tempo do direito, Trad. Élcio ernandes, Bauru: Edusc, 2005, p. 17.

${ }^{29}$ Outra grande problemática se dá também ente o Judiciário e a mídia, onde a problemática é de altíssima complexidades, para melhor compreender vide: ROCHA, Álvaro Felipe Oxley da. Sociologia do direito: A magistratura no espelho, São Leopoldo: Editora UNISINOS, 2002, p. 65 e ss.

30 "Para quem visualiza o sistema pela perspectiva de um operador forense, seu funcionamento não se mostra apenas insatisfatório. Mostra-se assustador. Como era de supor, a extraordinária litigiosidade que caracteriza nosso tempo, obriga os magistrados a padronizarem suas decisões, praticando - com maior ou menor vocação para o normativismo abstrato - uma jurisdição "pasteurizada", sem compromisso com o "caso"”. 
jurisdicional seriada e despreocupada com o caso em concreto, onde o que vale é decidir de forma rápida e se livra o quanto antes daquele processo $^{31}$, que é visto como mais um dos infindos fardos que o Judiciário carrega.

Essa "justiça pasteurizada" é maléfica, pois efetivamente limita os direitos dos cidadãos, a partir de uma análise descuidada e desmedida que é feita pelo Poder Judiciário, limitando, não somente os direitos que são pretendidos, mas também a própria condição de pensar do Poder Judiciário, que tem total liberdade intelectual para bem julgar ${ }^{32}$ e fundamentar ${ }^{33}$ suas decisões. Devemos buscar nos afastar dessa ocorrência que se mostrou desde logo terrível e maléfica, por colocar o cidadão em situação inconcebível e o próprio Judiciário em posição de desprestigio total.

Outro grande obstáculo que deve ser superado, e decorre de todas as práticas anteriormente referidas, é ocorrência dos "votos prontos" ${ }^{34}$ que são ofertados pelo próprio Poder Judiciário que, antes de tudo deveria prezar por seus julgados e buscar torná-los cada vez mais fortes e respeitáveis, afrontam, além de toda a boa prestação jurisdicional esperada do Judiciário, os direitos e a possibilidade jurídica de vitória da parte que recorre, ou ainda do

O autor ainda continuar:

"De qualquer modo, esta prática estimula o arbítrio, porque os julgadores, por várias razões e circunstâncias, julgam-se dispensados de fundamentar adequadamente as sentenças. Quem declara - apenas descompromissadamente declara -, não tem o que justificar. Não está obrigado a fundamentar a possível injustiça declarada, pela qual o declarante não é responsável". ( DA SILVA, Ovídio A. Baptista. Da função à estrutura www.Baptistadasilva.com.br/artigos).

${ }^{31}$ Sobre a idéia de formalismo no processo civil, deve-se observar a obra do jurista Carlos Alberto Alvaro de Oliveira, que refere a importância do formalismo, na medida adequada, sendo este formalismo, para ser aceitável, valorativo e não um formalismo despropositado que afoga o Poder Judiciário e prejudica a sistemática processual. (OLIVEIRA, Carlos Alberto Alvaro. Do formalismo no processo civil, $2^{\circ}$ ed. rev. e ampli., São Paulo: Saraiva, 2003).

${ }^{32}$ No sentido de observar o bem julgar propiciador da construção da democracia vide GARAPON, Antonie. Bem julgar: ensaio sobre o ritual judiciário, Lisboa: Instituto Piaget, 1997, p. 327.

33 A fundamentação que é requisito indispensável às decisões judicial, em principal a sentença, por ser a forma de convencer as partes da decisão que foi tomada, sendo esse dever de fundamentar do Judiciário uma garantia para o cidadão. Para compreender melhor a Idéia utilizada para o princípio da fundamentação, que para alguns é a mesma coisa que motivação, ver NERY JÚNIOR, Nelson. Princípios do processo civil na constituição federal, $7^{\circ}$ ed. rev. atual., São Paulo: RT, 2002, p. 180 e ss.

34 “A avalanche de recursos provoca uma extraordinária violência contra a Constituição. A causa é julgada privadamente. O julgamento não é público. Mesmo assim, ele se dá por unanimidade, sem que os demais componentes do colegiado proclamem publicamente seus votos. Para o público que assiste à sessão de julgamento, os votos dos demais magistrados, é um segredo, embora se fique sabendo depois que os votos resumiram-se ao tradicional "de acordo com o relator". É de supor que tenham votado também na véspera. As comunicações eletrônicas permitem que o julgamento colegiado se dê antes da abertura da sessão pública. Nesta, ouve-se apenas a voz do Presidente a proclamar o resultado". (DA SILVA, Ovídio A. Baptista. Da função à estrutura - www.Baptistadasilva.com.br/artigos). 
recorrente, pois os votos que são preparados antes mesmo do momento do julgamento do recurso, serão simplesmente lidos no dia marcado para o julgamento.

Sabe-se que o volume recursal é soberbo e que isso dificulta e muito a atividade dos julgadores, pois além de julgarem os feitos recursais, ainda devem observar os critérios de admissibilidade dos recursos, que tem a função de filtrar cada vez mais a possibilidade recursal, visando desafogar o Judiciário. Não se critica os critérios utilizados como requisitos de admissibilidade, pois estes são extremamente necessários, mas, sim, a má utilização desses critérios e por vezes, inclusive, em votos prontos, que impossibilitam o conhecimento do que realmente se busca discutir.

Essa problemática também é decorrência de todo o acumulo de trabalho que se agregou ao Poder Judiciário, fruto de tudo aquilo que discutimos sobre o Legislativo e as demais modalidades de surgimento de demandas que abarrotam o Judiciário.

Agrega-se a tudo isso, ainda, outra questão que se discute bastante, qual seja a da fundamentação das decisões judiciais, pois como sabemos essa necessidade de fundamentação é imprescindível, pois dota as decisões judiciais de força e de justificação.

As decisões judiciais devem ser fundamentadas ${ }^{35}$ demonstrando os argumentos jurígenos que foram utilizados pelo julgador, para que assim a parte possa se convencer da decisão, concordando ou não com ela. A questão fica ainda mais complexa depois que se percebe a existência de uma fundamentação incompleta, por mais que respeitando os critérios formais, como tem se dado, pois a decisão tem uma fundamentação, em tese, mas isso não é o bastante, pois uma fundamentação deve ser a clara explicação do Judiciário para o cidadão de que terá ou não o direito por tal razão jurídica e/ou fática.

Surge, para a nossa realidade processual caótica, uma crítica forte, mas pontuada e muito relevante para a mudança dessa realidade anacrônica, feita pelo douto jurista Ovídio A. Baptista da Silva baseado nas lições de Carnelutti e Chiovenda, sendo relevante um movimento de decisão interna do julgador, antes mesmo de decidir a causa e seus pedidos,

\footnotetext{
35 Bem assevera o art. 93, IX da Carta Política, verbis: “ IX todos os julgamentos dos órgãos do Poder Judiciário serão públicos, e fundamentadas todas as decisões, sob pena de nulidade, podendo a lei limitar a presença, em determinados atos, às próprias partes e a seus advogados, ou somente a estes, em casos nos quais a preservação do direito à intimidade do interessado no sigilo não prejudique o interesse público à informação".
} 
pois se o magistrado não se decidir, antes de tudo, menor será a sua condição de decidir a problemática judicial criada e posta a sua frente ${ }^{36}$.

É disso que se fala, de uma explicação efetiva dos motivos decisórios e não de um amontoado de palavras que não se servem a explicar qual tese adotada, ou ainda, qual a realidade fenomênica considerada, por tudo isso antes de qualquer manifestação judicial o julgador deve decidir a sua posição em relação a lide através das provas acostadas ao processo formando essa convicção pelo livre convencimento motivado ${ }^{37}$. Além disso, outra coisa se tem percebido e cada vez mais nas decisões judiciais é a decisão que fundamenta somente uma parte da questão, dizendo que uma das partes obteve o direito com base em uma determinada concepção jurídica, não explicando ao sucumbente o motivo da sua derrota. Isso é relevante, pois a fundamentação deve se dar no sentido de explicar ao vencedor o motivo de seu êxito e ao perdedor as razões de sua derrota. Tudo isso seria também uma forma de reduzir, pelo menos em tese, a incidência recursal, pois se convencida for a parte dos motivos de sua vitória ou derrota dificilmente virá a recorrer desta decisão, ou pelo menos causaria severa dúvida na busca da utilização do rol taxativo dos recursos.

Por fim, outro grande ponto decorrente de toda a problemática instalada é o enfraquecimento das decisões de $1^{\circ}$ grau, pela simples existência da possibilidade recursal livre. Tem-se percebido uma desvalorização natural da decisão do juízo de instancia inicial, que foi justamente aquele que teve contato com a prova, que ouviu o depoimento pessoal, que fez a inspeção judicial ou que produziu e colheu de forma pessoal as provas que fazem parte do processo. Esse magistrado deveria ter maior valorização tanto de sua atividade, de uma forma geral, como também de suas decisões, fazendo com que esse juiz fosse mais exigido, gerando um grau de responsabilidade maior por parte do juiz, não se limitando apenas a decidir as demandas. Compreendemos que essa ocorrência é uma das problemáticas da crise

\footnotetext{
36 "Daí porque, somente haverá autêntica decisão jurisdicional quando o sistema jurídico reconheça a seus juízes algum grau de discricionariedade, para que ele possa, como dissera Carnelutti, antes de decidir, "decidir-se". A discricionariedade, como todos sabem, está institucionalmente ausente na jurisdição apenas declaratória. Nossos juízes não decidem apenas julgam. Decidir é ato volitivo, julgar é ato intelectivo. Qualquer calouro em curso psicologia conhece essa distinção elementar. Decisão é ato de vontade, de que nossos magistrados estão institucionalmente privados, como dissera Chiovenda. Sim, pode haver "novas interpretações da lei velha", não porém "como mister do juiz" (DA SILVA, Ovídio A. Baptista. Da função à estrutura www.Baptistadasilva.com.br/artigos).

37 Vide MARINONI, Luiz Guilherme [et. all.]. Código de direito processual civil comentado, São Paulo: RT, 2008, p. 177-178; THEODORO JÚNIOR, Humberto. Curso de Direito Processual Civil: Teoria do Direito Processual Civil e o Processo de Conhecimento. $39^{\circ}$ ed., Rio de Janeiro: Forense, 2003, v.1, p. 38.
} 
vivenciada pelo Poder Judiciário, pois o juiz de $1^{\circ}$ grau tem sido desvalorizado e desmotivado por toda a exagerada possibilidade recursal decorrente de sua decisão ${ }^{38}$.

Assim, não há como falar da inexistência da crise do Judiciário, pois essa é inerente, mas deve-se falar sim em superação dessa crise que se implantou e que vem causando infindos prejuízos tanto para a sociedade que aguarda muito do Poder Judiciário como também dos próprios membros deste Poder, que foram preparados para serem, antes de tudo, juristas pensantes e que constroem a sociedade e lutam contra as desigualdades, buscando sempre a adimplência da Constituição Federal e dos direitos e garantias fundamentais expansíveis a todos os cidadãos e não meros repetidores da mesmice ou ainda a boca da lei. ${ }^{39}$

\section{A RELATIVIZAÇÃO DA COISA JULGADA}

O direito processual civil que é responsável pela solvência de várias questões litigiosas, estabelecendo regras especificas a serem seguidas para que haja um procedimento adequado e concatenado de atos que possam proporcionar o devido julgamento.

Esse julgamento respeitará os princípios processuais constitucionais ${ }^{40}$ garantindo aos litigantes o devido processo legal ${ }^{41}$ e seus consectários como o contraditório ${ }^{42}$, a celeridade ${ }^{43}$, a razoável duração do processo ${ }^{44}$ entre outros.

\footnotetext{
${ }^{38} \mathrm{O}$ posicionamento de Ovídio sobre o tema é o seguinte: "O risco de comprometerem-se com a causa, antes da sentença final, é um fator sistemático (conseqüentemente estrutural) predisposto para manter o juiz em sua natural passividade. O sistema recursal é o instrumento que vigia a observância desta imposição. É natural, portanto, que os juízes procurem não se envolver com as questões de mérito da causa, antes de poderem proclamá-la no momento adequado. Temos um magistrado concebido para manter-se passivamente neutro, durante o curso da relação processual".

O notável jurista ainda complementa sua argumentação argüindo que "O trágico produto do Racionalismo - que se esmerou em tornar o Direito uma "ciência", segundo o modelo matemático - foi dar-nos um "juiz irresponsável", metódica e institucionalmente irresponsável, cuja missão está limitada a declarar as injustiças cometidas pelo legislador”. (DA SILVA, Ovídio A. Baptista. Da função à estrutura www.Baptistadasilva.com.br/artigos).

${ }^{39}$ CHIOVENDA, Giuseppe. Principios del derecho procesal, Madri: Reus, s/d, p. 365.

${ }^{40}$ A Constituição Federal de 1988 traz em seu arcabouço diversos princípios processuais que são de imensa valia para o direito processual civil brasileiro, dos quais devem ser consultados nas obras: PORTANOVA, Rui. Princípios do processo civil, $6^{\circ}$ ed., Porto Alegre: Livraria do Advogado, 2005; e NERY JÚNIOR, Nelson. Princípios do processo civil na constituição federal, $7^{\circ}$ ed. rev. atual., São Paulo: RT, 2002.

${ }^{41}$ Nesse sentido aduz Nelson Nery Júnior que "O princípio fundamental do processo civil, que entendemos como base a qual todos os outros se sustentam, é o do devido processo legal, expressão oriunda da inglesa due
} 
Com a decisão judicial, em relação à questão, acontecerá, por natural, após a o transito em julgado aquilo que se chama de coisa julgada ${ }^{45}$, instituto jurígeno capaz de estabilizar as demandas visando a não discutibilidade ad eternum.

Esse instituto da coisa julgada - res iudicata - é um gerador de paz social, que acalma as partes e põe fim à discussão e controvérsias. Isso é positivo por atribuir um "fim"46 ao processo que se iniciou, buscando sempre a ocorrência da justiça ${ }^{47}$. A coisa julgada pode ser material $^{48}$ ou formal ${ }^{49}$, possuindo limite objetivo ${ }^{50}$ ou subjetivo $^{51}$.

process of Law. (...)" in NERY JÚNIOR, Nelson. Princípios do processo civil na constituição federal, $7^{\circ}$ ed. rev. atual., São Paulo: RT, 2002, p. 32.

${ }^{42}$ Idem., p. 134.

${ }^{43}$ Sobre a conceituação deste princípio ver PORTANOVA, Rui. Princípios do processo civil, $6^{\circ}$ ed., Porto Alegre: Livraria do Advogado, 2005, p. 171 e ss. Ademais, deve-se observar que a celeridade nem sempre garante justiça, por vezes o que se dá é o contrario pois a celeridade, por sua natureza, gera injustiças pela ausência de tempo para solucionar a problemática, afastando a idéia da justiça cidadã, in SANTOS, Boaventura de Souza. Para uma revolução democrática da justiça, $2^{\circ}$ ed., São Paulo: Cortez, 2008, p. 24.

${ }^{44}$ Para averiguar essa noção de razoável duração do processo veja-se: CARVALHO, Fabiano. EC n. 45: reafirmação da garantia da razoável duração do processo. In: WAMBIER, Teresa Arruda Alvim et al. (Coord.). Reforma do judiciário: primeiros ensaios críticos sobre a EC n. 45/2004. São Paulo: Revista dos Tribuinais, 2005, p.216. "Isso importa dizer que todos têm acesso à justiça para postular e obter uma tutela jurisdicional adequada. Nesse contexto, a prestação da tutela jurisdicional em tempo razoável garante o efetivo acesso à justiça, porquanto o direito à prestação jurisdicional dentro de um tempo aceitável é uma exigência da tutela jurisdicional efetiva".

${ }^{45}$ Para Pontes de Miranda "Quando da sentença não mais cabe recurso, há res iudicata. As questões, que havia, de fato e de direito, foram julgadas. Passa em julgado a decisão e não os fundamentos, e o que se julga de quaestiones facti apenas concerne a decisão". (MIRANDA, Pontes. Comentários ao Código de Processo Civil. Tomo V: arts. 444 a 475, 5. v. $3^{\circ}$ ed. Rio de Janeiro: Forense, 1997, p.111). Ademais, diz Liebman: "Ora, a coisa julgada (Rechtskraft) consiste na força vinculante da declaração, quer se apresente estar por si só na sentença, quer seja acompanhada de efeito constitutivo da espécie indicada; este efeito constitutivo, pois, nada tem que ver com a coisa julgada, absolutamente desnecessário para que ele se possa produzir". (LIEBMAN, Enrico Tullio. Eficácia e Autoridade da Sentença e outros escritos sobre a Coisa Julgada. $3^{\circ}$ ed. Rio de Janeiro: Forense, 1984, p. 18).

${ }^{46}$ Sabe-se que a idéia de processo foi modificada, não importando hoje no fim do processo após a sentença, pois hoje há como continuidade o cumprimento da sentença e não mais como antes que se encerrava o processo cognitivo com a sentença e depois se iniciava o processo de execução, essa realidade foi alterada para cumprir com a busca da aplicação da celeridade processual respeitando a razoável duração do processo.

${ }^{47}$ Sabemos que o critério de justiça é algo relativo, sendo por vezes inatingível, o que dificulta muito essa busca por aquilo que se entende ser justo, pois o justo pode ser visto conforme o seu ângulo, já que ara uma parte o justo será a procedência de seus pedidos, através da ação judicial, e para a parte adversa o justo será a improcedência dos pedidos. Eis a questão que é complexa por sua natureza. No dizer de Nelson Nery Júnior é uma utopia, in : NERY JÚNIOR, Nelson [et. all.]. Código de processo civil comentado e legislação extravagante, $10^{\circ}$ ed. rev., ampli. e atual., São Paulo: RT, 2007, p. 687.

${ }^{48}$ Solidificando a idéia do que seja coisa julgada material vem Pontes de Miranda aduzindo que "a coisa julgada material é a que impede discutir-se, noutro processo, o que se decidiu". (MIRANDA, Pontes. Comentários ao Código de Processo Civil. Tomo V: arts. 444 a 475, 5. v. $3^{\circ}$ ed., Rio de Janeiro: Forense, 1997, p. 111). Ainda vale a pena observar as colocações do processualista Ovídio A. Baptista da Silva, verbis: “(...) a coisa julgada material pressupõem a coisa julgada formal. Por outras palavras, para que haja imutabilidade da sentença no futuro, primeiro é necessário conseguir-se a sua indiscutibilidade na própria relação jurídica de onde ela provém. Não há coisa julgada material sem a prévia formação da coisa julgada formal, de modo que somente as sentenças 
Existem casos em que a decisão não é bem tomada, ou ainda, situações em que a realidade fática se altera, muda ainda a norma ou o entendimento do Tribunal que julgou de forma "definitiva" a questão, sendo esses casos autorizadores daquilo que modernamente se chama de relativização da coisa julgada ${ }^{52}$, que em verdade é uma flexibilização da coisa julgada, que anteriormente colocou, supostamente, fim a discussão judicial.

contra as quais não caibam mais recursos poderão produzir coisa julgada material”. (SILVA, Ovídio Araújo Baptista da. Curso de Processo Civil: processo de conhecimento. v. I. 5. ed. São Paulo: RT, 2001, p. 485).

${ }^{49}$ Sobre a coisa julgada formal vejamos as palavras do saudoso jurista Ovídio A. Baptista da silva referindo que "A esta estabilidade relativa, através da qual, uma vez proferida a sentença e exauridos os possíveis recursos contra ela admissíveis, não mais se poderá modificá-la na mesma relação processual, dá-se o nome de coisa julgada formal, por muitos definida como preclusão máxima (...)" (Idem., p. 484). Cabe por fim agregar a essa idéia as lições de Dinamarco, verbis: "A coisa julgada formal é a imutabilidade da sentença como ato jurídico processual. Consiste no impedimento de qualquer recurso ou expediente processual destinado a impugná-la, de modo que, naquele processo, nenhum outro julgamento se fará". E continua explicando que: "O fenômeno processual da irrecorribilidade, ou seja, da exclusão de todo e qualquer poder de provocar ou emitir nova decisão no processo, é a preclusão. E, como essa preclusão tem sobre o processo como um todo o efeito mortal de consumar sua extinção, tradicionalmente a doutrina diz proeclusio máxima para designar a coisa julgada formal". (DINAMARCO, Cândido Rangel. Instituições de Direito Processual Civil. 3 v. $2^{\circ}$ ed., São Paulo: Malheiros, 2002, p. 297-298).

${ }^{50}$ Este limite referem-se a que matérias serão analisadas na sentença, o conteúdo que será parte dela, separando o que fará ou não parte da res iudicata, o que para alguns faz coisa julgada somente o dispositivo e não o relatório e a fundamentação, para melhor compreensão vejamos o que nos diz Dinamarco: "Por objeto do processo entende-se a soma de todos os pedidos trazidos pelo autor originário e por outros eventuais demandantes, como o próprio autor ao denunciar a lide a terceiro, o réu em reconvenção ou também ao denunciar a lide ou chamar terceiro ao processo, ou o terceiro ao deduzir intervenção litisconsorcial voluntária ou oposição interventiva". (Idem., p. 314-315). Também Pontes de Miranda se manifesta entendendo assim: “(...) porque a coisa julgada é adstrita ao pedido e ao reconhecido pela sentença".(MIRANDA, Pontes. Comentários ao Código de Processo Civil. Tomo V: arts. 444 a 475, 5. v. $3^{\circ}$ ed., Rio de Janeiro: Forense, 1997, p. 122).

${ }^{51}$ Este limite da coisa julgada é referente aos sujeitos aos quais poderá ou não se limitar a produção de efeito da res iudicata, neste sentido CÂNDIDO RANGEL DINAMARCO entende que "a imutabilidade dos efeitos da sentença vincula somente os sujeitos que figuram no processo e aos quais se dirigiu aquela". (DINAMARCO, Cândido Rangel. Instituições de Direito Processual Civil. 3 v. 2. ed. São Paulo: Malheiros, 2002, pp. 316,317). Também entende nesse sentido Pontes de Miranda que "quanto aos limites subjetivos, a coisa julgada somente atinge as partes do processo (res iudicata ius facit inter partes)". (MIRANDA, Pontes. Comentários ao Código de Processo Civil. Tomo V: arts. 444 a 475, 5. v. $3^{\circ}$ ed., Rio de Janeiro: Forense, 1997, p. 122).

${ }^{52}$ Essa ocorrência pode se dar tanto no processo objetivo quanto subjetivo, incidindo, em tese e em parte, em uma mesma forma, veja assim alguns posicionamentos na doutrina que analisaram a questão, em nível de processo objetivo, e que foram determinantes para que se chegue a um entendimento razoável. Clèmersom Merlin Clève, observando o voto do ministro Carlos Veloso na ADC 1-1-DF, contribui argüindo que "É necessário, na ação de constitucionalidade, do mesmo modo que ocorre com a ação direta inconstitucionalidade, interpretar a coisa julgada e a eficácia erga omnes cum grano salis. Sim, porque a declaração de constitucionalidade de lei não pode impedir, diante de alteração das circunstâncias fáticas ou da realidade normativa, a propositura da ação direta de inconstitucionalidade. Embora por razões óbvias, a recíproca não seja verdadeira, hoje, a lei pode ser constitucional, amanhã não". (CLĖVE, Clèmersom Merlin. A fiscalização abstrata da constitucionalidade no direito brasileiro. $2^{\circ}$ ed., São Paulo: RT, 2000, p. 306). A coisa julgada nos processos objetivos ocorre nos mesmos moldes dos processos subjetivos. Parece claro, como foi dito, que, alteradas as circunstâncias jurídicas e o entendimento a respeito da norma que levou o Supremo Tribunal a determinada orientação, a coisa julgada anterior não impede a revisão do posicionamento porque toda coisa julgada tem, sempre, a clausula rebus sic stantibus.(Apud. LIEBMAN, Enrico Tullio. Eficácia e autoridade da Coisa Julgada, p. 25, trad. De Alfredo Buzaid e Benvindo Aires, notas de Ada Pellegrini Grinover). Gilmar Mendes afirma que "ação fundada em fato superveniente não é renovação de ação. É outra ação, com nova causa de pedir. Não se defronta com o obstáculo da coisa julgada”.(MENDES, Gilmar Ferreira. Jurisdição 
Essa relativização ${ }^{53}$ pode ocorrer através de uma ação rescisória ${ }^{54}$ - conforme a sistemática do art. 485 e seguintes do Código de Processo Civil - essa ação tem a finalidade de relativizar a res iudicata, visando maior efetivação da justiça ${ }^{55}$.

Existem outras maneiras de flexibilizar a coisa julgada, podendo ser via ação anulatória ou ainda por ação declaratória com a finalidade especifica de desconstituir a coisa julgada.

A relativização da coisa julgada pode ocorrer tanto nos Tribunas inferiores como nos superiores, tanto pelo processo objetivo como subjetivo, dando maior amplitude a essa discussão que muito influi na realidade que cada uma das partes viverá.

Essa idéia da relativização da res iudicata por vezes tem sido mal compreendida, sendo por essa razão rejeitada por alguns ${ }^{56}$. A resistência a noção da relativização, que

constitucional. $3^{\circ}$ ed., São Paulo: Saraiva, 1999, p. 291). Assim, Lenio Streck argumenta que não há, pois, um caráter absoluto na decisão que declara, de forma direta ou indireta, a constitucionalidade de um ato normativo, uma vez que a mutação do contexto social-histórico pode acarretar uma nova interpretação. Por isso, a hermenêutica de matriz fenomenológica pode contribuir para a elucidação dessa problemática, uma vez que o processo de interpretação é sempre produtivo (Sinngebung), e não meramente reprodutivo (Auslegung). Uma lei pode ser constitucional em um dado momento histórico e inconstitucional em outro. (STRECK, Lenio Luiz. Jurisdição constitucional e hermenêutica: uma nova crítica do direito. $2^{\circ}$ ed., Rio de Janeiro: Forense, 2004 , p. 569). Por fim, Clèmersom Merlin Clève aduz que "a coisa julgada, entretanto, não "congela" ("engessa") de modo definitivo a jurisprudência do Supremo Tribunal Federal, já que no Brasil, como nos demais países (EUA, por exemplo) a alteração das circunstancias fáticas pode autorizar o deslocamento da compreensão constitucional de dada matéria. Assim, declarada a constitucionalidade de uma determinada lei, em virtude da sentença que julga improcedente a ação direta, não está impedido o Supremo Tribunal Federal de, mais tarde, uma vez alterado o sentido da norma paramétrica ou mesmo da normativa-objeto, e quando devidamente provocado decretar a inconstitucionalidade do dispositivo atacado". (CLÈVE, Clèmersom Merlin. A fiscalização abstrata da constitucionalidade no direito brasileiro. $2^{\circ}$ ed., São Paulo: RT, 2000, p. 240).

53 Autorizada doutrina vem sustentando a relativização da coisa julgada material. Trata-se de matéria delicada. Como a coisa julgada tem fundamento "eminentemente pragmático", não há razão para "santificá-la", ou para acobertá-la de proteção inquebrantável. Aliás, a lei prevê uma serie ampla de casos de sua rescindibilidade, admitida ainda a rescisão de julgamento proferido em rescisória. (ARAUJO CINTRA, Antonio Carlos de. Comentários ao código de processo civil. 4 v. arts: 332 a 475. Rio de Janeiro: Forense, 2003, p. 305).

${ }^{54}$ Sobre a utilização da ação rescisória observar as ponderações de Nelson Nery Júnior in: NERY JÚNIOR, Nelson [et. all.]. Código de processo civil comentado e legislação extravagante, $10^{\circ}$ ed. rev., ampli. e atual., São Paulo: RT, 2007, p. 776 e ss.

55 "Os institutos de direito material estão destinados, diria que naturalmente, a mudar de acordo com o surgimento e a diferente avaliação dos interesses em conflito em relação à fruição dos bens materiais e imateriais. Diferentemente dos institutos de direito material, os institutos processuais que visam garantir a tutela jurisdicional dos direitos nascem, por assim dizer, não apenas com o selo terreno, mas com aquele da eternidade, que lhes é aposto por seu próprio destino de garantir a realização da justiça”(Andrea Proto Pisani, Revista da Escola da Magistratura do Rio de Janeiro, n. 16, 2001, p. 23).

${ }^{56}$ Idem., p. 685 e ss. 
aduzimos neste trabalho, se dá pelo temor da ocorrência de violação da segurança jurídica ${ }^{57}$, que sabemos ser relevante.

A segurança jurídica é, por vezes, produzida pela coisa julgada, visto que essa torna as problemáticas sentenciadas e transitadas em julgado "definitivas" gerando uma idéia de segurança jurídica ao sistema, produzindo-se, por consectário, a paz social ${ }^{58}$.

Embora esses fundamentos sejam fortes não podemos esquecer que por vezes injustiças são causadas aos cidadãos, que buscam do Judiciário a devida solução, sendo que por vezes injustiças são efetivadas e erros ocorrem causando sofrimento e muitos problemas.

É para essas problemáticas que se presta a relativização da coisa julgada, não para buscar o absurdo e incorreto, mas, sim, o que é correto, a correção daquilo que foi efetivado de forma errada, produzindo o tão esperado senso de justiça ${ }^{59}$.

Essas celeumas devem ser sanadas a tempo de causar o menor prejuízo possível às partes. Não se busca, com a flexibilização da coisa julgada, aquilo que não será possível, ou ainda, uma saída maliciosa ao caso concreto, mas, efetivamente, aquilo que é possível e correto, mas que não se aplicou por algum motivo, seja ele um erro material, alteração fática, mudança de entendimento dos tribunais ou da própria lei ${ }^{60}$, neste caso desde que venham em benefício do sujeito que busca a medida de flexibilização da coisa julgada.

\footnotetext{
${ }^{57}$ Idem., p. 687. Também observar Carlos Aurélio Mota de Souza que refere que a segurança está implícita no valor justiça, sendo um 'a priori' jurídico. O doutrinador afirma ainda que se a lei é garantia de estabilidade das relações jurídicas, a segurança se destina a estas e às pessoas em relação; é um conceito objetivo, a priori, conceito finalístico da lei. (SOUZA, Carlos Aurélio Mota de - Segurança Jurídica e Jurisprudência: um enfoque filosófico-jurídico - São Paulo : LTr, 1996, p. 128). Acerca dos elementos que dão efetividade ao princípio, temos que a segurança jurídica é assegurada pelos princípios seguintes: irretroatividade da lei, coisa julgada, respeito aos direitos adquiridos, respeito ao ato jurídico perfeito, outorga de ampla defesa e contraditório aos acusados em geral, ficção do conhecimento obrigatório da lei, prévia lei para a configuração de crimes e transgressões e cominação de penas, declarações de direitos e garantias individuais, justiça social, devido processo legal, independência do Poder Judiciário, vedação de tribunais de exceção, vedação de julgamentos parciais, etc. (MARTINS, Eliezer Pereira - Segurança Jurídica e Certeza do Direito, publicado no site www.jus.com.br).

${ }^{58}$ Nesse ponto o jurista Nelson Nery Júnior aponta no sentido de que a segurança jurídica mantém o Estado Democrático de Direito, sendo uma peça fundamental para a questão, assim vide: NERY JÚNIOR, Nelson [et. all.]. Código de processo civil comentado e legislação extravagante, $10^{\circ}$ ed. rev., ampli. e atual., São Paulo: RT, 2007 , p. 686 e ss.

${ }^{59}$ A lei jurídica passou a ser, efetivamente, uma expressão de consenso político e social, busca-se, nada mais do que, uma solução razoável para conflitos naturais que os seres humanos vivenciam. (Chaim Perelman, Ética e direito, São Paulo: Martins Fontes, 1996, p. 377.)

${ }^{60}$ Quando se fala de lei, se pensa em normativismo, devemos alertar a posição de renomados autores sobre essa idéia de normativsmo, assim vide: “(...) cada vez mais fatores vêm impondo a superação de todas as formas de normativismo dogmático, em prol da compreensão hermenêutica do direito processual. Um deles, talvez o mais
} 
A questão é realmente a busca da prática coerente no caso concreto. Isso que deve ser levado em conta, pois os institutos jurídicos devem ter utilidade prática e que alcancem o seu fim de efetivar direitos ${ }^{61}$.

Não se está aqui a defender o impossível e o inatingível, mas, sim, aquilo que a própria doutrina vem possibilitando. Assim, a relativização pode ocorrer, facilmente, nas demandas que discutem a paternidade de uma criança, em decorrência de decisão judicial anterior que não contava com o DNA, que é exame mais forte em seu grau de certeza, e considerou não haver relação entre as partes do processo, mas que com a feitura do DNA e descobrindo a relação de parentesco pode fazer com que aquela sentença que havia transitado em julgado seja quebrada e relativizada para ofertar à criança o direito de ter um pai e que esses se relacionem vivenciando ambos a magnífica experiência da relação parental. ${ }^{62}$

Também se pode falar em relativização da coisa julgada nos processos frente ao Supremo Tribunal Federal, seja no controle difuso ou no concentrado. Neste podendo chegar ao Supremo através da ADI, ADC ou ainda pela ADPF, por via de consequiência naquele podendo chegar a Corte Suprema através do Recurso Extraordinário.

Podemos dizer que nessa via de discussão a situação seja mais complexa, pois estaremos discutindo a coisa julgada, que sempre foi vista como um dogma ${ }^{63}$, que já é

notável, é a profunda transformação do conceito de lei, abandonando o conceito iluminista de lei, que haveria de portar uma "vontade" invariável inserida no texto pelo legislador". (SILVA, Ovídio A. Baptista da. Jurisdição, direito material e processo, Rio de Janeiro: Forense, 2008, p. 141.). Neste sentido também pontua Castanheira Neves (O instituto dos "assentos" e a função jurídica dos tribunais supremos, Coimbra, 1983, p. 584).

${ }^{61}$ Efetivar os direitos fazendo com que os direitos sejam levados a sério seguindo a idéia de Ronald Dowrkin vide: DWORKIN, Ronald. Levando os direitos a sério, trad. Nelson Boeira, São Paulo: Martins Fontes, 2002, p. 283 e ss.

62 Neste sentido vejamos o julgado do Tribunal de Justiça Gaúcho, através do douto Desembargador Rui Portanova in verbis: APELAÇÃO CÍVEL. NEGATÓRIA DE PATERNIDADE. EXTINÇÃO DO PROCESSO SEM RESOLUÇÃO DO MÉRITO EM FACE DA COISA JULGADA. Atualmente, os efeitos da coisa julgada, em ações de investigação de paternidade, sofrem alguma distenção, em face da possibilidade de um juízo de certeza advinda dos avanços do DNA. Some-se a isso, o fato de estarmos diante de ação de estado, onde a natureza da pretensão i declaratória i é imprescritível, bem como não se operam os efeitos da revelia (art. 320, inciso II do CPC). Circunstâncias que obrigam, em certos casos, a relativização da coisa julgada, em face da natureza e da importância do direito em discussão. APELAÇÃO PROVIDA EM MONOCRÁTICA PARA DAR SEGUIMENTO À AÇÃO. (Apelação Cível No 70022570949, Oitava Câmara Cível, Tribunal de Justiça do RS, Relator: Rui Portanova, Julgado em 25/02/2008).

${ }^{63}$ Muito interessante observar a argüição feita pelo filósofo alemão Arthur Shopenhauer in: SCHOPENHAUER, Arthur. Como vencer um debate sem precisar ter razão: em 38 estratagemas, trad. Daniela Caldas e Olavo de Carvalho, Rio de Janeiro: Topbooks, 1997, p. 168-169. Para o saudoso jurista Ovídio A. Baptista da Silva "a transformação paradigmática, da qual não nos é possível escapar, sob pena de renunciar ao direito, como instrumento superior de resolução de conflitos sociais, ao mesmo tempo em que permitirá resgatar a figura do juiz "responsável" - oposto ao juiz do sistema, que não comete injustiças, porquanto sua missão está limitada a 
complexa de alterar e também pela discussão ser efetivada no nível de uma Corte que é muito apegada ais institutos e regras jurídicas positivadas, o que causa certa dificuldade em fazer com que essa ponderação seja aceita com facilidade.

Com tudo isso, devemos asseverar que o próprio Ministro Gilmar Mendes, em sua tese doutoral, acolheu o posicionamento do Tribunal Constitucional Alemão no sentindo de relativizar a coisa julgada, o que demonstra, por mais que de forma simplória, a abertura desta Corte Máxima no sentido de discutir e até mesmo aceitar a relativização ${ }^{64}$.

Considerando a relativização da res iudicata, muita coisa muda, até porque ocorrendo isso outra problemática se colocará a frente de todos, qual seja o efeito aplicável, seja ex $\operatorname{tunc}^{65}$ ou ex nunc ${ }^{66}$. Isso trará muita repercussão, pois dotará de retroatividade ou não a decisão que relativizou a coisa julgada.

Por sua vez no processo objetivo a questão será a possibilidade de eficácia inter partes $^{67}$ ou ainda erga omnes ${ }^{68}$, que influirá muito na questão, pois poderá delimitar se o alcance da decisão será somente entre as partes ou se abarcará a todos.

declarar a injustiça da lei -, determinará que o pensamento jurídico renuncie ao dogmatismo, para recuperar a função hermenêutica na compreensão de textos, sob o pressuposto epistemológico de que o texto carrega várias soluções jurídicas possível, para, enfim, mostrando que texto e norma não são a mesma coisa, reentronizar a retórica como ciência da argumentação forense, que o pensamento linear dos juristas geômetras do século XVII pretendeu eliminar do direito processual”. (SILVA, Ovídio A. Baptista da. Jurisdição, direito material e processo, Rio de Janeiro: Forense, 2008, p. 148.)

${ }^{64}$ Neste sentido e embasado nas lições de Bryde, Gilmar Ferreira Mendes aduz que: Assim sendo, declarada a constitucionalidade de uma lei, ter-se-á de concluir pela inadmissibilidade de que o Tribunal se ocupe, uma vez mais, da aferição de sua legitimidade, ressalvadas as hipóteses de significativas mudanças fáticas ou de relevante alteração das concepções jurídicas relevantes. Também entre nós se reconhece, tal como ensinado por Liebman com arrimo em Savigny, que as sentenças contem implicitamente a clausula rebus sic stantibus, de modo que as alterações posteriores que modifiquem a situação normativa, bem como eventual mudança da orientação jurídica sobre a matéria, podem tornar inconstitucional a norma anteriormente considerada legitima(inconstitucionalidade superveniente).Daí parece-nos plenamente legitimo que se argua, perante o Supremo Tribunal Federal, a inconstitucionalidade de norma anteriormente declarada constitucional em ação direta de constitucionalidade.(MENDES, Gilmar Ferreira. Jurisdição constitucional. $3^{\circ}$ ed., São Paulo: Saraiva, 1999, p. 294 e 295).

65 Como efeitos retroativos, que aplicam a nova decisão anulando a anterior, retroagindo a todos aos atos anteriores à nova decisão para afastá-los, fezendo com que esses passam a não existir considerando esses atos como nunca antes existentes, neste sentido ver: MORAES, Alexandre de. Direito constitucional. 19. ed. São Paulo: Atlas, 2006, p. 651.

${ }^{66}$ Com efeitos que seão considerados a partir de então, a contar da decisão que fixou a geração de efeitos determinados, nesse sentido SILVA, José Afonso da. Curso de direito constitucional positivo. 20. ed. São Paulo: Malheiros, 2001, p. 54.

${ }^{67}$ No sentido de entender bem a eficácia inter partes, que restringe a força decisória entre as partes litigantes, veja-se: MIRANDA, Jorge. Teoria do estado e constituição. Rio de Janeiro, 2002, p. 505; SILVA, José Afonso da. Curso de direito constitucional positivo. 20. ed. São Paulo: Malheiros, 2001, p. 53 a 54; BARACHO, José 
Tudo isso é imperioso cuidar de forma concreta, para que as consequiências naturais da decisão que pode relativizar determinada questão surtam suas eficácias corretas e posteriores efeitos adequados.

\section{A RELATIVIZAÇÃo dA COISA JULGADA COMO DECORRÊNCIA DA CRISE DO PODER JUDICIÁRIO.}

De toda essa abordagem que efetivamos podemos abstrair a necessária existência da relativização da coisa julgada, assim como a de outros institutos jurídicos, para que o sistema $^{69}$ seja balanceado e possa chegar o fim pretendido qual seja a feitura de justiça ${ }^{70}$.

Com toda essa peculiaridade o que podemos perceber é a existência da crise do Poder Judiciário como algo a ser combatido por todos os juristas e não somente pelos próprios membros desse Poder.

Essa crise do judiciário afeta a todos, tanto os juristas como os não-juristas, que labutam por seus direitos dia a dia, por ser uma ocorrência que interfere inclusive em vários institutos jurídicos dentre eles o da coisa julgada.

A crise vivenciada pelo Judiciário é decorrente de tudo o que já foi exposto anteriormente, sendo consectário da inação do Legislativo, ausência de fundamentação

Alfredo de Oliveira. Direito constitucional contemporâneo: homenagem ao Professor Paulo Bonavides/ Fernando Luiz Ximenes Rocha e Filomeno Moraes, organizadores. Belo Horizonte: Del Rey, 2005, p. 492.

${ }^{68}$ Sobre a eficácia erga omnes, que limita o conteúdo decisório a todos, a indicação fica pela obra de José Affonso da Silva in: SILVA, José Afonso da. Curso de direito constitucional positivo. 20. ed. São Paulo: Malheiros, 2001, p. 54.

${ }^{69}$ Que pode ser analisado na perspectiva de Niklas Luhmann, quando defende a idéia de uma teoria sistêmica do direito, chegando a uma conclusão de que o sistema jurídico se auto-reproduz, sendo isso a autopoiese. Esse processo que se renova sendo capaz de auto-reprodução foi abordado pelo autor LUHMANN, Niklas. Sitemi sociali: Fondamenti di una teoria generale, Bolonha:Il Mulino, 1990, p. 64.

${ }^{70}$ Deve-se buscar a justiça, que é sim o fundamento e a esperança de todos que demanda, não buscando, entretanto, a justiça estática, que não será capaz de chegar ao ponto que a justiça efetiva poderia chegar. Assim vejamos Agnes Heller - quando fala da "justiça estática" - justiça do tirando, justiça da verdade do senhor. ( Agnes Heller, Más Allá de la justicia, Barcelona: editora crítica, 1990, p. 311 e ss.). Ademais, a justiça perfeita jamais se encontrará, o que nos motiva, atualmente, a buscar a justiça de forma moderada e não através de uma pretensiosa e ilusória noção de justiça, neste sentido Ovídio A. Baptista da Silva - trás a idéia de ser, a justiça perfeita, pathos tirânico de nossa herança iluminista, sendo uma justiça que se tornou normativa, fugindo da vida real para tornar-se apenas conceitual. (Ovídio A. Baptista da Silva. Processo e ideologia, forense, 2004, p. 17.) 
adequada aos julgados, a crescente demanda que se impõe a cada dia frente ao Poder Judiciário e entre outras ocorrências que preocupam a todos.

A coisa julgada também sofre com a ocorrência da crise que se implantou no Poder Judiciário, visto que esse poder acaba por solver os conflitos, por vezes, de forma inadequada ou ainda incorreta. Essa prática, que merece ser reformada, atinge a todos os tipos de pessoas que demandam direitos através do processo, tentando fazer valer seus direitos fundamentais ${ }^{71}$.

A crise fez com que o Poder Judiciário perdesse, por vezes, o foco, decidindo vários processos de forma seriada sem atentar ao detalhe de cada caso que altera e muito a possível solução.

Tudo se deu e se dá pela busca desenfreada da celeridade, que deve ser pretendida e achada, mas que não pode ser o fundamento básico e único de um decisum ${ }^{72}$. O magistrado deve sim buscar a solução rápida ${ }^{73}$, mas dentro de uma razoável duração do processo e não decidir de forma a prestigiar somente a celeridade, pois como se sabe a celeridade desacompanhada da idéia de razoável duração do processo é falha.

\footnotetext{
${ }^{71}$ Sobre os variados direitos fundamentais que os cidadão possuem vejamos as obras: CANOTILHO, José Joaquim Gomes. Estudos sobre direitos fundamentais, $2^{\circ}$ ed., Portugal: Coimbra Editora, 2008; ALEXY, Robert. Teoria dos direitos fundamentais, trad. Virgilio Afonso da Silva, São Paulo: Malheiros, 2008.

72 Deve-se tomar muito cuidado com essa idéia de celeridade que é buscada por todos, sabendo, como já referido, que a celeridade sem cautela passa a ser um problema e não uma solução, torna a análise mais problemática e perigosa, gerando por vezes injustiças. Umas das formas de utilizar a celeridade para descongestionar o Judiciário é a utilização das sumulas vinculantes e do efeito vinculante, neste sentido SANTOS, Boaventura de Souza. Para uma revolução democrática da justiça, $2^{\circ}$ ed., São Paulo: Cortez, 2008, p. 25.

${ }^{73}$ No sentido de agilidade Boaventura de Souza Santos refere que o pacto de Estado em favor de um Judiciário mais ágil e Republicano foi firmado pelas autoridades máximas dos três poderes da república brasileira que convergiram em 11 compromissos fundamentais para o aperfeiçoamento do sistema judicial: 1) Implementação da reforma constitucional do judiciário; 2) reforma do sistema recursal e dos procedimentos; 3) defensoria pública e acesso à justiça; 4) juizados especiais e justiça itinerante; 5) execução fiscal; 6) precatórios; 7) graves violações contra direitos humanos; 8)informatização; 9) produção de dados e indicadores estatísticos; 10) coerência entre a atuação administrativa e orientações jurisprudenciais já pacificadas; 11) incentivo à aplicação de penas alternativas. Um dos resultados mais visíveis do pacto foi a aprovação de alterações legislativas, notadamente no processo civil. Dentre as principais mudanças promovidas destaco: 1) Lei $\mathrm{n}^{\circ} 11.187 / 05$, agravos, racionaliza a utilização dos agravos que passam a ser julgados apenas no momento da apelação evitando o seu uso para fins protelatórios; 2) Lei $\mathrm{n}^{\circ} 11.232 / 05$, execução de títulos judiciais, unifica o processo de conhecimento, liquidação e execução de sentença dispensando notificação pessoal do réu após a citação; 3) Lei $\mathrm{n}^{\mathrm{o}} 11.277 / 06$, processos repetitivos, racionaliza o julgamento de processos repetitivos, permitindo ao juiz dispensar a citação do réu e julgar a acção improcedente se a controvérsia exclusivamente de direito e já tiver sido julgada improcedente em diversos casos idênticos submetidas ao mesmo juízo, 4) Lei $\mathrm{n}^{\circ} 11.341 / 06$, processo eletrônico, disciplina a adoção de meios eletrônicos para a prática dos actos judiciais. (SANTOS, Boaventura de Souza. Para uma revolução democrática da justiça, $2^{\circ}$ ed., São Paulo: Cortez, 2008, p. 26).
} 
Assim, deve o Judiciário buscar a decisão adequada de forma célere, mas dentro do que é razoavelmente aceitável para a solução da lide, dentro do tempo ${ }^{74}$ do processo, sem acelerar, desnecessariamente, o processo.

Frente a todas essas ocorrências não há duvidas de que a relativização da coisa julgada, além de outros fundamentos, adveio também dessa idéia de crise do Judiciário, que fez como que esse Poder se imbuísse de uma busca incoerente de celeridade a qualquer preço esquecendo o real fundamento do processo e da existência das partes que figuram no processo, qual seja a solvência dos conflitos e a entrega do bem da vida ${ }^{75}$ a quem de direito.

Essa realidade caótica deve ser revista em busca de uma solução à tamanha crise, que já causou celeumas de grande esfera, como esta da relativização da coisa julgada, que foi criada para superar o erro judicial, a alteração da realidade fática existente no processo, alteração do entendimento do Tribunal ou até mesmo a alteração legal que também causará mudanças na forma de decidir uma lide.

De todas as formas já referidas supra, que são ensejadouras da caracterização da relativização da coisa julgada, o judiciário se coloca com mais frequiência, efetivamente, na do erro judicial, que por vezes se dá pelo excessivo volume de processos que os magistrados detém, quer pelo avolumando números de recursos que o sistema prevê e quer pela morosidade natural que o próprio sistema processual civil nacional entronizou.

Tudo isso é fundamento bastante para que o Judiciário venha a chegar no estágio em que se encontra, estagio de caos, o que também é decorrência do parco numero de magistrados que o Estado disponibiliza, além de não fomentar na comunidade do próprio Poder o devido treinamento ${ }^{76}$ e formação direcionada à solução rápida dos processos respeitando a razoável duração do processo. Esse treinamento seria muito relevante para os novos membros do Judiciário, treinando-os para o exercício desse cargo que ocupa relevância destacada frente à sociedade, por ser o responsável em levar, àqueles que tanto buscam, a tão

\footnotetext{
${ }^{74}$ Assim como a sociedade tem seu tempo, como já dizia François Ost, o processo e o direito também tem o seu tempo em sua justa medida. (OST, François. O tempo do direito, Trad. Élcio ernandes, Bauru: Edusc, 2005, p. 23).

${ }^{75}$ É expressão utilizada por alguns processualista para determinar o bem ou a coisa que está sendo objeto da disputa judicial.

${ }^{76}$ SANTOS, Boaventura de Souza. Para uma revolução democrática da justiça, $2^{\circ}$ ed., São Paulo: Cortez, 2008, p. 66 e ss.
} 
esperada realização da justiça, efetivação e respeito dos direitos que cada um dos cidadãos, que se transmutam em demandantes, possui.

Todas essas ocorrências aliadas trazem resultados gravosos a todos, tanto aos cidadãos que buscam no Judiciário a resposta "correta"77 para seus problemas, como também aos advogados e demais operadores do direito, que, com essa crise, se encontram em situação de perplexidade frente ao verdadeiro descaso para com todos os princípios que norteiam o ordenamento jurídico ${ }^{78}$.

A solução imediata que a doutrina apontou, para solver a problemática pelo menos por enquanto, foi relativizar a coisa julgada, o que é, para muitos, incompreensível mas bem acentuada e necessária para salvaguardar aos cidadãos, que são litigantes, das injustiças e equívocos que passam vir a se dar.

Exemplos problemáticos não faltam para averiguar a relativização. Vejamos os casos diversos que são ocorrentes em que os magistrados decidem de forma igual às ações repetitivas, e que em um caso em que o pleiteante venha a fazer uma nova ponderação naquele tipo de ação, que deveria ser observado cuidadosamente pelo Judiciário, mas que não o foi, pois o Magistrado, por todo o volume de trabalho existente, acaba por não averiguar o pedido efetivado e acaba por decidir da mesma forma que tem feito em relação às outras demandas supostamente idênticas. É nesses casos que entra em jogo a utilidade da flexibilização da res iudicata.

A situação ainda piora quando o Magistrado já detém uma sentença de total improcedência em uma questão, o que pode motivar a decisão do Judiciário em conformidade com o art. 285-A do Código de Processo Civil, onde o Juiz poderá decidir de forma idêntica a que tem feito em sentenças anteriores, dispensando-se, inclusive, a citação da parte adversa.

\footnotetext{
${ }^{77}$ Sabe-se que resposta correta é algo utópico, pois a verdades distintas a partir de uma das modalidades de observação pode ser diferente, cada uma das parte tem a sua idéia do seja correto, assim a expressão que se utiliza é no sentido de que o judiciário se manifeste e decida o conflito ao menos de forma satisfatória, respeitando os princípio e regras processuais existentes em nosso ordenamento jurídico.

${ }^{78}$ BOBIO, Norberto. Teoria do ordenamento jurídico, trad. Maria Celeste Cordeiro Leite dos Santos, $10^{\circ}$ ed., Brasília: Editora Universidade de Brasília, 1999, p. 71 e ss.
} 
Lembre-se que a discussão deve ser exclusivamente de direito, não devendo haver ponderações fáticas a serem efetivadas, sob pena de descaracterizar a aplicação do $285-\mathrm{A}^{79}$.

Essa medida que o Código Processual Civil adotou é natural em busca da celeridade, mas deve-se cuidar para que a celeridade a qualquer custo não macule a garantia de um devido processo legal, que é gênero do qual são espécies o contraditório e a ampla defesa.

Essa é mais uma ocorrência que deriva da crise do Poder Judiciário, que agora vive em busca da celeridade, mas que não o faz da forma mais adequada, por esquecer dos demais princípios de índole Constitucional.

Com tudo isso, voltando a observar a crise do Judiciário sob o prisma da coisa julgada, é latente a ocorrência da relativização, para instalar a idéia de correção daquilo que foi decidido e "efetivado" como correto através do ato judicial.

Todos estão sujeitos ao erro inclusive o Judiciário, que detém volume exacerbado de demandas para analisar, ai está a grande possibilidade de relativização da coisa julgada, seja na via do processo subjetivo ou na via do processo objetivo. Esse erro deve ser sanado e pode ser por via da ação rescisória, que possibilita, sem o mínimo embargo, a relativização da res iudicata, ou ainda, pela via das ações declaratórias.

Assim, alterando a noção até então "absoluta" da coisa julgado poderemos chegar a outra realidade, abandonando a decisão judicial equivocada, utilizando a alteração fática, a alteração legislativa ou a alteração do posicionamento de um determinado Tribunal ou até do magistrado em posicionamento singular.

Frente a toda essa problemática, analisando a sistemática processual, podemos crer que uma das possíveis soluções seja a de dotar o magistrado de mais responsabilidade ${ }^{80}$ para

\footnotetext{
${ }^{79}$ Efetivamente é uma medida radical e muito brusca, que pode afetar direitos dos cidadãos, até porque cada caso guarda a sua peculiaridade o que muda, pelo menos em tese, o liame de observação que deve ser efetivada. Essa prerrogativa que o magistrado hoje possui é advinda das reformas hodiernas ao Código de Processo Civil, que visando a celeridade passou a autorizar praticas como esta que está sob análise. O art. 285-A do Código de Processo Civil, que prevê tal ocorrência está sob judice sob relatoria do Mim. Cezar Peluso, através da ADI 3.695/DF, sendo atacado, tal dispositivo, de inconstitucional, até o presente momento não houve decisão que declarasse a (in)constitucionalidade do tal dispositivo. Esse dispositivo junto com outros são a efetiva ocorrência da racionalização da atividade jurídica que visa compatibilizar as decisões judiciais de forma vertical, visando a maior economia processual, assim refere MARINONI, Luiz Guilherme [et. all.]. Código de direito processual civil comentado, São Paulo: RT, 2008, p. 294. Deve ficar claro que para que seja aplicável esse dispositivo do Código de Processo Civil é necessário que a sentença seja de improcedência, sendo necessariamente em caso parecido ao anteriormente decido, sob pena de não poder ser aplicado o referido artigo. (Idem., pp.294-295).
} 
que esse venha, antes de qualquer outro sujeito, valorizar a sua própria decisão, sabendo que pode por ela ser responsabilizado. Isso dotaria o magistrado de maior dever obrigação para com os processos que venham a estar sob seus cuidados.

Além dessa prática que pode ser implantada e viabilizada, outra prática que pode auxiliar e muito a superação da crise do Poder Judiciário é a de uma observação mais rigorosa da fundamentação ${ }^{81}$ que é emanada pelo Magistrado, buscando-se que a fundamentação seja eficiente e forte, sendo uma motivação capaz de convencer ao vencido de sua derrota, convencendo-o a não utilizar, por vezes, os recursos processualmente cabíveis, pois a decisão foi tão adequada que se a parte sucumbente perceberá que recorrer talvez não seja o caminho para reformar uma decisão tão embasada e fundamentada ${ }^{82}$.

Essa fundamentação ${ }^{83}$ é aquela que diga ao sucumbente o porquê de sua derrota e ao vencedor o motivo de sua vitória ${ }^{84}$, e não simplesmente uma fundamentação que se preste a

\footnotetext{
${ }^{80}$ Nesse sentido SANTOS, Boaventura de Souza. Para uma revolução democrática da justiça, $2^{\circ}$ ed., São Paulo: Cortez, 2008, p. 69.

${ }^{81}$ A fundamentação que é requisito juridicamente necessário para que uma decisão seja apta a gerar seus efeitos naturais, deve contar com uma fundamentação eficaz ao ponto de convencer aos sujeitos que recebe a motivação emanada pelo Judiciário, fugindo-se da falsas fundamentações que são altamente reprovadas, assim como já referia o douto jurista Ovídio A. Baptista da Silva, verbis: "As falsas fundamentações que, hoje, são empregadas pelo Poder judiciário, são responsáveis por arbitrariedades que muito prejudicam o desenvolvimento nacional". ( SILVA, Ovídio A. Baptista da. Jurisdição, direito material e processo, Rio de Janeiro: Forense, 2008, p. 141). Essas sentenças que estão com "roupagem formosa", em relação à esperada fundamentação, não passam de mero pronunciamento judicial sem a devida análise por parte do julgador, o que gera em diversas hipóteses "sentenças arbitrarias". (neste sentido Genaro R. Carrió e Alejandro D Carrió, El recurso extraordinario por sentencia arbitrria, Buenos Aires, Abeledo-perrot, 1983).

${ }^{82}$ Para Ovídio A. Baptista da Silva “(...) é correto dizer que o número de recursos aumenta na proporção em que aumenta o número de provimentos judiciais carentes de fundamentação. O resultado inverso também é verdadeiro: quanto mais bem-fundamentado o ato jurisdicional tanto menor será o número de recursos que podem atacar." ( SILVA, Ovídio A. Baptista da. Jurisdição, direito material e processo, Rio de Janeiro: Forense, 2008, p. 156.)

${ }^{83}$ Para que se chegue a uma fundamentação adequada o julgador deve formar a partir das provas o chamado livre convencimento motivado, que propiciará uma sentença de qualidade e que poderá se servi a seu fim social. Vejamos o que a doutrina tem observado sobre a questão: No dizer de Pontes de Miranda: "livre convencimento é o convencimento a que se chegou com todo o material de prova"(Comentários ao código de processo civil, forense, 1974, tomo II, p. 383.) Segundo Ovídio "há, portanto, duas exigências impostas ao julgador. A primeira, determinando que ele se "persuada" racionalmente, formando o convencimento a partir dos "fatos e circunstancias" constantes dos autos; depois, impondo-lhe que explicite seu convencimento, através da análise crítica do conjunto da prova, bem como que justifique também a interpretação do direito aplicável." (SILVA, Ovídio A. Baptista da. Jurisdição, direito material e processo, Rio de Janeiro: Forense, 2008, p. 152.) Esse tipo de sentença que venha a adimplir com esses requisitos será uma sentença que respeitará a "completeza" que é argüida por TARUFFO( La testimonianza della parte nel sistema dell'oralità, Giuffrè, 1974, p. 144).

${ }^{84}$ Continua o jurista a referir que o juiz ao decidir e fundamentar deve, além de analisar os pontos apresentados pelo vencedor em que concorde e se convença serem verdadeiros, deve também analisar os argumentos da parte sucumbente com o fim de demonstrar que o perdedor não teria se quer razão. (Idem., p. 151.) Neste sentido também temos a lição de TARUFFO.(Senso comune, esperienza e scienza nel ragionamento del giudice, in revista trimestrale di diritto e procedura civile, Giuffrè, p. 675, 2001, trad. Candido Rangel dinamarco.)
} 
dizer unicamente que uma das partes tem direito, sem explanar profundamente o porquê e ainda sem referir a outra parte o motivo de não ter acolhido a sua tese.

A fundamentação ${ }^{85}$ adequada é um ideal a ser pretendido e buscado ${ }^{86}$, por não ser impossível, embora seja trabalhoso. Todo o trabalho será válido, pois dotará as decisões de maior força e aceitabilidade por parte de todos inclusive dos advogados, dotando, ademais, o próprio Magistrado de maior respeitabilidade por parte da população ${ }^{87}$.

Ainda outra possível solução a ser aplicada, em conjunto com as demais, é a de permitir ao Judiciário buscar a celeridade, mas utilizando nessa busca a noção de manutenção do contraditório e da ampla defesa, além de respeitar a razoável duração do processo ${ }^{88}$.

Essa é uma busca necessária, a da celeridade, mas não nos moldes em que tem sido efetivada, pois como tem sido aplicada acabou por ser desrespeitadora da razoável duração do processo, pois por vezes, é tão célere que não permite a ocorrência probatória, além de ser tão célere ao ponto de romper com o princípio do contraditório e da ampla defesa, diga-se, por exemplo, em casos que venham a ser aplicado o art. 285-A do Código de Processo Civil ${ }^{89}$.

Com isso, fica demonstrada, neste trabalho, a existência real da crise do Poder Judiciário que deve ser se não solucionada, pelo menos amenizada, visando a inocorrência de

${ }^{85}$ O jurista Ovídio A. Baptista da Silva já afirmava que a sentença deve guardar uma linguagem acessível a todos, até mesmo aos leigos, para que seja uma fundamentação ideal. ( SILVA, Ovídio A. Baptista da. Jurisdição, direito material e processo, Rio de Janeiro: Forense, 2008, p. 155.)

${ }^{86}$ A crítica de Ovídio A. Baptista da Silva em relação à fundamentação aduzindo que em raríssimos casos, nossos juízes preocupam-se com as "circunstâncias constantes dos autos". Em virtude de um vício de nossa formação jurídica, costumamos trabalhar com conceitos, conseqüentemente com regras, desprezando as "circunstâncias constantes nos autos". (Idem., p. 146).

${ }^{87}$ A fundamentação bem posta e com a devida cautela, em sua elaboração, "ao invés de diminuir a autoridade do magistrado, a motivação das sentenças dá-lhes prestígio perante o público" ( Moacyr Amaral dos Santos. A prova judiciária no civil e no criminal, Rio de Janeiro: Max Limonad, 1952, 1. Vol., p. 395.)

88 A necessidade de respeitar todos esses princípio é natural por se tratar de princípios processuais constitucionais, que são fonte de todo o arcabouço processual civil vigente, estando esses princípios previsto no art. $5^{\circ}$ (contraditório e ampla defesa) LV - aos litigantes, em processo judicial ou administrativo, e aos acusados em geral são assegurados o contraditório e ampla defesa, com os meios e recursos a ela inerentes e (razoável duração doprocesso) LXXVIII - a todos, no âmbito judicial e administrativo, são assegurados a razoável duração do processo e os meios que garantam a celeridade de sua tramitação.

${ }^{89}$ Nesse sentido vejamos situação jurisprudencial que demonstra bem a questão, especificamente no processo $\mathrm{n}^{\mathrm{o}}$ 001/1.09.0158058-2 que tramita na Justiça Estadual gaúcha, discutindo sobre a legalidade ou não do repasse econômico que foi efetivado no caso concreto. Verbis: “(...) Em processos anteriores já analisei a mesma matéria, tendo julgado improcedente por entender que não há ilicitude na conduta da ré em repassar as contribuições relativas ao PIS e COFINS, como no processo $\mathrm{n}^{\circ}$ 1.09.0039026-7, assim decidindo (...)

(...) Assim, utilizando-me da faculdade do art. 285-A do Código do Processo Civil (acrescentado pela Lei $\mathrm{n}^{\circ}$ 11.277/2006), julgo improcedente esta AÇÃO ORDINÁRIA proposta por NEUSA LOPES WOCJCIECHOVSKI contra BRASIL TELECOM S/A e Empresa de Telefonia Oi (...)" 
novos danos aos cidadãos que vão ao Judiciário buscando a solução de seus problemas e que por vezes acabam por obter mais problemas do que soluções, como era esperado.

Deve-se alertar que, frente a toda essa ocorrência de crise, não existe um único Poder ou agente a ser responsabilizado, mas, sim, uma somatória de várias ocorrências que foram se agregando e causando esse enorme problema que hoje é intitulado de crise do Poder Judiciário e que todos sofrem e carregam juntos as conseqüências.

Assim, o dever de interpretar ${ }^{90}$ e buscar a solução adequada a essa crise, que favoreceu a ocorrência da relativização da coisa julgada, é de todos os juristas, Poderes, agentes e cidadãos. Não porque está se estendendo a todos a problemática, mas porque a solução pode ser ofertada por cada um desses personagens que vivenciam as ocorrências processuais dia a dia, o que lhes dota de maior facilidade em buscar e aplicar uma solução que seja a mais eficaz.

Dentre a análise que se perfilhou neste trabalho, cremos que as soluções são as mais variadas possíveis, mas que aquelas que foram aqui apontadas são as de maior aplicabilidade imediata, justamente por serem possíveis de colocar em prática, gerando desde logo o objetivo pretendido.

Tudo isso poderá dotar a sistemática processual civil brasileiro de maior celeridade, efetividade $^{91}$, respeitando o contraditório e a ampla defesa, dentro da noção de razoável duração do processo, responsabilizando ainda mais o magistrado por suas decisões, que deveram fundamentar estas de forma adequada sendo cada vez mais comprometidos com a melhor solução para a lide, satisfazendo a todos os participantes da lide e fazendo com que se não se extermine a crise do Judiciário, que pelo menos a amenize a situação que foi e é, ainda hoje, muito debatida.

\footnotetext{
${ }^{90}$ Sobre a hermenêutica filosófica, que se vale a noção de interpretação, deve ser consultado GADAMER, HansGeorg. Verdade e método II, trad. Enio Paulo Gianchini e Maria Sá Cavalcante Schuback, Petrópolis: Vozes, 2002 , p. 111 e ss.

${ }^{91}$ Uma obra excelente foi construída pelo jurista gaúcho Darci Ribeiro, quando em seus estudos doutorais, sendo uma análise pontuada e que passou também pela idéia de tutela judicial efetiva, que é aquilo que muito se busca em nossa comunidade jurídica. In: RIBEIRO, Darci Guimarães. La pretensión procesal y La tutela judicial efectiva, Barcelona: J.M.Bosch editor, 2004, p. 75 e ss. Também observar a lições de BEDAQUE, José Roberto dos Santos. Efetividade do processo e técnica processual, $2^{\circ}$ ed., São Paulo: Malheiros, 2007, p. 49 e ss.
} 


\section{CONSIDERAÇÕES FINAIS}

Realmente, a crise do Judiciário se instalou, sem pedir licença, e já causou imensos problemas para todos, em principal para aqueles que litigam e buscam a efetivação de seus direitos. Essa crise, que é advinda da crise em outros ramos da vida que são conexos com o direito, foi importante para chegarmos hoje a noção que temos sobre a crise.

A crise do judiciário se deu e precisava ser contida, se não amenizada, sendo esse o ponto em que entra a relativização da coisa julgada, que será aplicável nos casos em que haja injustiça e problemáticas que merecem um cuidado especial.

Essa realidade de relativizar a res iudicata é naturalmente posta e deve ser aceita para que decisões mal tomadas não prejudiquem aos cidadãos que muito lutaram e sofreram para adquirir uma determinada condição de vida,

Solucionar a crise do Judiciário é algo muito complexo, por ser uma crise que se instalou a um bom tempo e que aparenta crescer a cada dia.

Mecanismos que foram estudados para a busca do afastamento da crise do Poder Judiciário são vários, indo desde a maior valorização das decisões de primeiro grau, dotando o magistrado de mais responsabilidade frente a seu julgado, como também e da devida aplicação da fundamentação das decisões judiciais.

Tudo isso deve ser observado com os olhos da celeridade, que deve ser respeitada e bem usada, como não foi até o presente momento, pois deve a idéia de celeridade ser observada frente a razoável duração do processo, mantendo o contraditório e a ampla defesa.

Assim, acabamos por entender que a crise do Judiciário poder ser amenizada, e quem sabe com muito investimento até encerrada, sendo uma crise que repercuti em todos os cidadãos que dependam do Judiciário para que seus direitos e deveres entrem em ação.

Concluímos afirmando que a crise não é um monstro, mas se mal cuidada pode se transforma, causando diversos prejuízos, ocorrentes através dos atos decisórios dos magistrados, que por vezes são incorretos e problemáticos ao ponto de precisarem ser relativizados para que quem mereça o direito e possa recebê-lo, ou ainda, buscá-lo. 


\section{REFERÊNCIAS BIBLIOGRÁFICAS}

ALEXY, Robert. Teoria dos direitos fundamentais. Trad. Virgilio Afonso da Silva. São Paulo: Malheiros, 2008.

ARAUjO CINTRA, Antonio Carlos de. Comentários ao Código de Processo Civil. 4 v. arts: 332 a 475. Rio de Janeiro: Forense, 2003.

BARACHO, José Alfredo de Oliveira. Direito constitucional contemporâneo: homenagem ao Professor Paulo Bonavides. Fernando Luiz Ximenes Rocha e Filomeno Moraes (org.) Belo Horizonte: Del Rey, 2005.

BAUMAN, Zygmunt. Modernidade e ambivalência. Rio de Janiro: Jorge Zahar Editor, 1999.

BEDAUQE, José Roberto dos Santos. Direito e processo: influência do direito material sobre o processo. $4^{\mathrm{o}}$ ed., rev. e ampli., São Paulo: Malheiros, 2006. . Efetividade do processo e técnica processual. $2^{\circ}$ ed. São Paulo: Malheiros, 2007.

BOBIO, Norberto. Teoria do ordenamento jurídico. trad. Maria Celeste Cordeiro Leite dos Santos. $10^{\circ}$ ed. Brasília: Editora Universidade de Brasília, 1999.

CAMPBELL, C. The Romantic Ethic and the Spirit of Modern Consumerism. Oxford: Blackwell, 1987.

CANOTILHO, José Joaquim Gomes. Estudos sobre direitos fundamentais. $2^{\circ}$ ed. Portugal: Coimbra Editora, 2008.

CARRIÓ, Genaro R. e CARRIÓ, Alejandro D. El recurso extraordinario por sentencia arbitrria. Buenos Aires, Abeledo-perrot, 1983.

CARVALHO, Fabiano. EC n. 45: reafirmação da garantia da razoável duração do processo. In: WAMBIER, Teresa Arruda Alvim et al. (Coord.). Reforma do judiciário: primeiros ensaios críticos sobre a EC n. 45/2004. São Paulo: RT, 2005.

CASTANHEIRA NEVES, Antonio. O direito hoje em com que sentido? Lisboa: Editora Piaget, 2002.

O instituto dos "assentos" e a função jurídica dos tribunais supremos. Coimbra, 1983.

CHIOVENDA, Giuseppe. Principios del derecho procesal. Madri: Reus, s/d.

CLÈVE, Clèmersom Merlin. A fiscalização abstrata da constitucionalidade no direito brasileiro. $2^{\circ}$ ed., São Paulo: RT, 2000. 
DELACAMPAGNE, C. História da filosofia no Século XX. Rio de Janeiro: Jorge Zahar Editor, 1995.

DINAMARCO, Cândido Rangel. A Instrumentalidade do processo. $9^{\circ}$ ed. São Paulo: Malheiros, 2001. . Instituições de direito processual civil. $2^{\circ}$ ed., São Paulo: Malheiros, 3 v., 2002.

DUVERGER, Maurice. Constitutions et documents politiques. Paris: PUF, 1974.

DWORKIN, Ronald. Levando os direitos a sério. Trad. Nelson Boeira. São Paulo: Martins Fontes, 2002.

FEATHERSTONE. Cultura de consumo e pós-modernismo. São Paulo: Studio Nobel, SESC, 1995.

GADAMER, Hans-Georg. Verdade e método II. Trad. Enio Paulo Gianchini e Maria Sá Cavalcante Schuback. Petrópolis: Vozes, 2002.

GARAPON, Antonie. Bem julgar: ensaio sobre o ritual judiciário. Lisboa: Instituto Piaget, 1997.

GIDDENS. "A vida em uma sociedade pós-tradicional”, In: BECK, GIDDENS \& LASH, 1997.

ENDES, Gilmar Ferreira. Jurisdição constitucional. $3^{\circ}$ ed., São Paulo: Saraiva, 1999.

HARVEY, David. Condição pós-moderna. São Paulo: Edições Loyola, 1992.

HELLER, Agnes. Mas allá de la justicia. Barcelona: Editorial Crítica, versão espanhola de 1990.

JAYME, Erik. Cours général de droit intenacional prive, In recueil des cours. Académie de droit intenacional, t, 251, 1997.

KELSEN, Hans. Teoria pura do direito. $4^{\circ}$ Ed. São Paulo: Martins Fontes, 1994.

KATO, Shelma Lombardi de. A crise do direito e o compromisso da libertação. In Direito e justiça: a função social do Judiciário. José Eduardo Faria (org.). $3^{\circ}$ ed.. São Paulo: Ática, 1997.

KUMAR, Krishan. Da sociedade pós-industrial à pós-moderna. Rio de Janeiro: Jorge Zahar Editor, 1997.

LABOULAYE, Edouard René Lefebvre de. Do Poder Judiciário. In: O poder judiciário e a Constituição. Porto Alegre: coleção AJURIS 4, 1977.

LIEBMAN, Enrico Tullio. Eficácia e autoridade da sentença e outros escritos sobre a coisa julgada. $3^{\circ}$ ed.. Rio de Janeiro: Forense, 1984. 
LYOTARD, Jean-François. O pós-moderno. Rio de Janeiro: Olympio Editora, 1986.

LOPES, José Reinaldo de Lima, in: FARIA, José Eduardo (coord.) [et. all]. Direito e justiça: a função social do judiciário, São Paulo: Ática, 1989.

LUHMANN, Niklas. Sitemi sociali: fondamenti di una teoria generale. Bolonha:Il Mulino, 1990.

MARINONI, Luiz Guilherme [et. all.]. Código de direito processual civil comentado. São Paulo: RT, 2008.

MARQUES, Claudia Lima. Contratos no código de defesa do consumidor: o novo regime das relações contratuais. 4. ed. rev., atual. e ampli., incluindo mais de 1.000 decisões jurisprudenciais. São Paulo, RT, 2002.

MARTINS, Eliezer Pereira. Segurança jurídica e certeza do direito. Publicado no site www.jus.com.br.

MIRANDA, Jorge. Teoria do estado e constituição. Rio de Janeiro, 2002.

MIRANDA, Pontes. Comentários ao Código de Processo Civil. $3^{\circ}$ ed. Rio de Janeiro: Forense, Tomo V: arts. 444 a 475, 5. v., 1997.

MONTESQUIEU, Charles de Secondat, Baron de. Do espírito das leis. São Paulo: Saraiva, 2000

MORAES, Alexandre de. Direito constitucional. 19. ed. São Paulo: Atlas, 2006.

NERY JÚNIOR, Nelson. Princípios do processo civil na Constituição Federal. $7^{\circ}$ ed. São Paulo: RT, 2002.

[et. all.]. Código de Processo Civil comentado e legislação extravagante. $10^{\circ}$ ed. rev., ampli. e atual. São Paulo: RT, 2007.

NEVES, Antônio Castanheira. O direito hoje em com que sentido? Lisboa: Editora Piaget, 2002.

OLIVEIRA, Carlos Alberto Alvaro. Do formalismo no processo civil. $2^{\circ}$ ed., rev. e ampl. São Paulo: Saraiva, 2003.

OST, François. O tempo do direito. Lisboa: Instituto Piaget, 1999. . O tempo do direito, Trad. Élcio ernandes, Bauru: Edusc, 2005.

PERELMAN, Chaim. Ética e direito. São Paulo: Martins Fontes, 1996.

PICORDI, Nicola. La vocazione del nostro tempo per la giurisdizione. Revista Trimestral de Diritto Procedura Civile, Giuffrè, 2004. 
PIÇARRA, Nuno. A Separação dos Poderes como doutrina e princípio constitucional: um contributo para o estudo das suas origens e evolução. Coimbra: Coimbra Editora, 1989.

PISANI, Andrea Proto. Revista da Escola da Magistratura do Rio de Janeiro, n. 16, 2001.

PORTANOVA, Rui. Princípios do processo civil. $6^{\circ}$ ed. Porto Alegre: Livraria do Advogado, 2005.

REALE, Miguel. Crise do capitalismo e crise do Estado. São Paulo: Editora SENAC, 2000.

RIBEIRO, Darci Guimarães. La pretensión procesal y la tutela judicial efectiva. Barcelona: J.M.Bosch editor, 2004.

ROCCO, Ugo. Trattato di diritto processuale civile. $2^{\circ}$ ed. Torino: Topografia Sociale Torinese, V. I, 1966.

ROCHA, Álvaro Felipe Oxley da. Sociologia do direito: a magistratura no espelho. São Leopoldo: Editora UNISINOS, 2002.

SANTOS, Boaventura de Souza. Para uma revolução democrática da justiça. $2^{\circ}$ ed. São Paulo: Cortez, 2008.

. Pela mão de Alice: o social e o político na pós-modernidade. São Paulo: Cortez, 1997.

SANTOS, Moacir Amaral. A prova judiciária no civil e no criminal. Rio de Janeiro: Max Limonad, 1952. . Primeiras linhas de direito processual civil. $7^{\circ}$ ed. São Paulo: Saraiva, 1980.

SCHOPENHAUER, Arthur. Como vencer um debate sem precisar ter razão: em 38 estratagemas. Trad. Daniela Caldas e Olavo de Carvalho. Rio de Janeiro: Topbooks, 1997.

SILVA, Ovídio Araújo Baptista da. Curso de processo civil: processo de conhecimento. 5. ed. São Paulo: RT, . v. I., 2001. . Da função à estrutura. www.Baptistadasilva.com.br/artigos) . Jurisdição, direito material e processo. Forense, 2007. . In: Participação e processo. Ada Pellegrini Grinover (coord.). São Paulo: RT, 1988. . Processo e ideologia. Forense, 2004.

SILVA, José Afonso da. Curso de direito constitucional positivo. 20. ed. São Paulo: Malheiros, 2001. 
SOUZA, Carlos Aurélio Mota de. Segurança jurídica e jurisprudência: um enfoque filosófico-jurídico. São Paulo : LTr, 1996.

STRECK, Lenio Luiz. Jurisdição constitucional e hermenêutica: uma nova crítica do direito. $2^{\circ}$ ed. Rio de Janeiro: Forense, 2004.

THEODORO JÚNIOR, Humberto. Curso de direito processual civil: teoria do direito processual civil e o processo de conhecimento. $39^{\circ}$ ed., Rio de Janeiro: Forense, 2003.

TOCQUEVILLE, Alexis de. La démocratie em Amérique. Paris: Garnier: Flammarion, t. II., 1951.

TARUFFO. La testimonianza della parte nel sistema dell'oralità. Giuffrè, 1974.

Senso comune, esperienza e scienza nel ragionamento del giudice, in revista trimestrale di diritto e procedura civile. Trad. Cândido Rangel Dinamarco. Giuffrè, 2001.

VATTIMO, Gianni. O fim da modernidade: niilismo e hermenêutica na cultura pós-moderna. Lisboa: Editorial Presença, 1987.

WAMBIER, Tereza Arruda Alvim [et.al]. O dogma da coisa julgada: hipóteses de relativização. São Paulo: RT, 2003. 